\title{
Modeling the impacts of biomass burning on air quality in and around Mexico City
}

\author{
W. Lei ${ }^{1}$, G. Li $^{1,2, *}$, and L. T. Molina ${ }^{1,2}$ \\ ${ }^{1}$ Molina Center for Energy and the Environment, La Jolla, CA, USA \\ ${ }^{2}$ Department of Earth, Atmospheric and Planetary Sciences, Massachusetts Institute of Technology, Cambridge, MA, USA \\ * now at: Key Laboratory of Aerosol, SKLLQG, Institute of Earth Environment, Chinese Academy of Sciences, Xi'an, China
}

Correspondence to: W. Lei (wflei@mce2.org) and L. T. Molina (ltmolina@mit.edu)

Received: 30 May 2012 - Published in Atmos. Chem. Phys. Discuss.: 5 September 2012

Revised: 22 January 2013 - Accepted: 14 February 2013 - Published: 1 March 2013

\begin{abstract}
The local and regional impacts of open fires and trash burning on ground-level ozone $\left(\mathrm{O}_{3}\right)$ and fine carbonaceous aerosols in the Mexico City Metropolitan Area (MCMA) and surrounding region during two high fire periods in March 2006 have been evaluated using WRFCHEM model. The model captured reasonably well the measurement-derived magnitude and temporal variation of the biomass burning organic aerosol (BBOA), and the simulated impacts of open fires on organic aerosol (OA) were consistent with many observation-based estimates. We did not detect significant effects of open fires and trash burning on surface $\mathrm{O}_{3}$ concentrations in the MCMA and surrounding region. In contrast, they had important influences on OA and elemental carbon (EC), increasing primary OA (POA) by $\sim 60 \%$, secondary OA (SOA) by $\sim 22 \%$, total OA (TOA $=\mathrm{POA}+\mathrm{SOA})$ by $\sim 33 \%$, and EC by $\sim 22 \%$, on both the local (urban) and regional scales. Although the emissions of trash burning are substantially lower than those from open fires, trash burning made slightly smaller but comparable contributions to OA as open fires did, and exerted an even higher influence on EC. Of the $\sim 22 \%$ enhancement in SOA concentrations (equivalent to a $\sim 15 \%$ increase in TOA) simulated, about two third was attributed to the open fires and one-third to the trash burning. On the annual basis and taking the biofuel use emissions into consideration, we estimated that open fires, trash burning and biofuel use together contributed about $60 \%$ to the loading of POA, $30 \%$ to SOA, and $25 \%$ to EC in both the MCMA and its surrounding region, of which the open fires and trash burning contributed about $35 \%$ to POA, $18 \%$ to SOA, and $15 \%$ to EC. The estimates of biomass burning impacts in this study may contain consid-
\end{abstract}

erable uncertainties due to the uncertainties in their emission estimates in magnitude, temporal and spatial distribution, extrapolations and the nature of spot comparison. More observation and modeling studies are needed to accurately assess the impacts of biomass burning on tropospheric chemistry, regional and global air quality, and climate change.

\section{Introduction}

Biomass burning (BB), generally defined as open or quasiopen combustion of any non-fossilized vegetative or organic fuel, such as open fires in forests, savannas, agricultural lands, and biofuel burning (Akagi et al., 2011), is the largest source of primary carbonaceous aerosols and the second largest source of trace gases in the global troposphere (Andreae, 1991; Andreae and Merlet, 2001; Bond et al., 2004), contributing about $20-40 \%$ of $\mathrm{CO}, \mathrm{NO}_{\mathrm{x}}$ and non-methane hydrocarbons, and $>35 \%$ of particulate organic carbon (OC). The trace gases and particulates emitted by or formed in the biomass burning plumes adversely affect human health and have important impacts on tropospheric chemistry, regional and global air quality, and climate change.

The air quality and atmospheric chemistry in the Mexico City Metropolitan Area (MCMA) is frequently affected by open biomass burning in the nearby mountains and savannas surrounding the city (Molina et al., 2010; Yokelson et al., 2011). Previous studies indicated that biomass burning can be an important contributor to fine particulate matter $(\mathrm{PM})$ in the MCMA during the dry season 
(Bravo et al., 2002; Molina et al., 2007), particularly to organic aerosol (OA), which comprises approximately half of the total fine PM (Salcedo et al., 2006; DeCarlo et al., 2008; Kleinman et al., 2008; Aiken et al., 2009). Extensive multiplatform measurements during the MILAGRO (Megacity Initiative: Local And Global Research Observations) campaign in 2006 in the MCMA and the surrounding areas further demonstrated the important role of BB in OA loading and its air quality and climate impacts (Molina et al., 2010). The estimated BB influences on OA using different apportionment techniques from the multi-platform measurements during MILAGRO are highly variable. Using potassium $\left(\mathrm{K}^{+}\right)$as the BB tracer, Moffet et al. (2008) reported that BB contributed $40 \%$ to the submicron particle (PM1) number observed at the urban supersite (T0) using aerosol timeof-flight mass spectrometry (ATOFMS). Based on a chemical mass balance $(\mathrm{CMB})$ analysis of molecular marker species (levoglucosan) measured from ground-based filter samples, Stone et al. (2008) found that BB contributed 5-26\% (average $11 \%$ ) to particulate $\mathrm{OC}$ mass in the urban area and $7-39 \%$ (average 16\%) in the suburban area of Mexico City. Querol et al. (2008) estimated about a 5-15\% contribution of $\mathrm{BB}$ to $\mathrm{PM}_{2.5}$ (fine particles below $2.5 \mu \mathrm{m}$ in aerodynamic diameter) (9-27\% to OA) concentrations in Mexico City according to their ground-based filter PM measurements and chemical analysis. Liu et al. (2009) reported a lower limit of $8 \%$ contribution of BB to submicron PM in the Mexico City urban area based on a Positive Matrix Factorization (PMF) analysis of FTIR and X-ray Fluorescence (XRF) measurements of organic functional groups and elemental composition. From the same data set, Gilardoni et al. (2009) further estimated that BB contributed an upper limit of about 30$40 \%$ to OC using non-soil $K$ as the biomass burning tracer. de Gouw et al. (2009) estimated that the BB contribution to OC lay between $7 \%$ and $39 \%$ (mostly below $30 \%$ ) on the ground in the suburban supersite (T1) based on the correlation between the enhancement ratio of acetonitrile $\left(\mathrm{CH}_{3} \mathrm{CN}\right)$ to CO and a CMB analysis. Aiken et al. $(2009,2010)$ used PMF analysis of Aerosol Mass Spectrometer (AMS) data measured at $\mathrm{T} 0$ and determined that $\mathrm{BB}$ contributed $15-23 \%$ of the OA in general in Mexico City during MILAGRO and 23-31\% during the high fire periods. Marley et al. (2009a) and Aiken et al. (2010) employed measurements of modern carbon $\left({ }^{14} \mathrm{C}\right)$ to estimate the impacts of $\mathrm{BB}$ on OC. Although there was a significant discrepancy in the reported ${ }^{14} \mathrm{C}$ estimates, both groups found that OC was enhanced by $\sim 13 \%$ during high $\mathrm{BB}$ periods.

Aircraft observations around the MCMA during MILAGRO-2006 reported relatively higher contributions of BB to OA than surface measurements; this could be due to the afternoon aircraft sampling time and the major BB being forest fires above the Mexico City basin. Yokelson et al. (2007) estimated that mountain fires surrounding the MCMA contributed about $50 \pm 30 \%$ of $\mathrm{PM}_{2.5}$ in the outflow based on aircraft measurements of $\mathrm{HCN}$ and $\mathrm{CO}$ and also by coupling fire emission factors with estimated biomass consumption and comparing to the official MCMA emission inventory. Crounse et al. (2009), using aircraft measurements of $\mathrm{BB}$ and urban emission tracers (hydrogen cyanide $(\mathrm{HCN})$ and ethyne $\left(\mathrm{C}_{2} \mathrm{H}_{2}\right)$, respectively) over and around the Mexico City basin, estimated that $\mathrm{BB}$ contributed about two- thirds of the OA (and one-third of $\mathrm{CO}$, benzene and $\mathrm{NO}_{\mathrm{y}}$ ) in the MCMA outflow, while at the surface the $\mathrm{BB}$ contribution to the OA was reduced to about $25 \%$. DeCarlo et al. (2010) applied PMF analysis to high time resolution AMS OA data acquired on the C-130 flying over the MCMA and the Central Mexico Plateau during MILAGRO, and reported that $\mathrm{BB}$ accounted for about $66 \%$ of the total OA mass during a high fire event in this region.

To date model-based studies of the BB impact on PM and other pollutants in the MCMA have been limited. Emmons et al. (2010) used tagged tracers in a global modeling study and concluded that open fires did not make a dominant contribution to $\mathrm{CO}, \mathrm{NO}_{\mathrm{x}}$ and $\mathrm{O}_{3}$ in this region, but they did not assess the impact of fires on PM. Fast et al. (2009) considered open fire emissions and compared their modeled POA to airborne measurements of POA. They concluded that the $\mathrm{BB}$ emissions of some large fires may be overestimated and that the timing of the biomass burning OA was not well simulated. Thus, the BB impact was not quantified with a bounded range. The model overestimation may also be due to biases in the placement of the fire smoke injection altitude or/and the transport of the smoke plumes. Hodzic et al. (2010a) predicted the contribution of BB to total OA in the MCMA, but they had large discrepancies with the observations in both the magnitude and temporal-spatial variation, particularly the timing. Thus, they did not attempt to definitively quantify the BB contribution to carbonaceous aerosols. Aiken et al. (2010) used particle dispersion analysis (FLEXPART) to qualitatively investigate the BB impact, and found that a later starting time for smoldering emissions improved the prediction of fire impacts, and that local fires were the dominant source for in situ biomass burning organic aerosols (BBOA) with small contributions from distant fires. Yokelson et al. (2009) suggested that distant fires (e.g., from the Yucatan) could make higher contributions to the Mexico City basin aerosol during El-Nino years.

The above measurement results, which are summarized in Table 1, show that BB could be an important contributor to fine PM and especially OA concentrations in Mexico City, with an even larger impact aloft and on the urban outflow. The results also indicate that the BB impact on the atmospheric composition, particularly $\mathrm{OA}$, is highly variable with large variations between different estimates. This is likely due to several factors, such as the use of different apportionment approaches and their associated limitations, difficulties in estimating the amount of biomass burned, emission characterization, and emission factors, etc. Also note that different metrics (OA, OC, $\mathrm{PM}_{1}$, etc.) are used in different estimations. Given the importance of BB to many radiatively 
Table 1. Measurement-based estimates of BB contributions to aerosol in the MCMA and/or its outflow.

\begin{tabular}{lllll}
\hline Source & Method & Variable & $\begin{array}{l}\text { Platform/ } \\
\text { Site }\end{array}$ & $\begin{array}{l}\text { Contribution } \\
(\%)\end{array}$ \\
\hline $\begin{array}{llll}\text { Moffet et al. (2008) } \\
\text { Stone et al. (2008) }\end{array}$ & ATOFMS /K-tracer & PM1 number & T0 & 40 \\
& Filter sampling/ & OC & T0 & $5-26$ \\
Tracer CMB & & T1 & $7-39$ \\
& $\begin{array}{l}\text { Filter sampling/BB-OC } \\
\text { relation in Stone et al. (2008) }\end{array}$ & OA & T0 & $9-27$ \\
Liu et al (2009) & FTIR/XRF/PMF & PM1 & T0 & 8 \\
Gilardoni et al. (2009) & FTIR/XRF/K-tracer & OC & T0 & $30-40$ \\
de Gouw et al. (2009) & ATOFMS/ & OC & T1 & $7-39$ \\
& Tracer CMB & OA & T0 & $15-23$ \\
Aiken et al. (2010) & AMS/PMF & OC & T0 & 13 \\
& 14 C & OC & T0 & 13 \\
Marley et al. (2009a) & 14 C & PM 2.5 & Aircraft outflow & $20-80$ \\
Yokelson et al. (2007) & FTIR/EI & OA & Aircraft outflow & 66 \\
Crounse et al. (2009) & CIMS/BB tracer & & surface & 25 \\
& & OA & Aircraft outflow & 66 \\
DeCarlo et al. (2010) & AMS/PMF & & & \\
\hline
\end{tabular}

and chemically active gases and particulates in this region, it is of great interest to validate a model that can be used to assess the impacts during periods without measurements or to provide an independent estimate of the BB contribution. Validated simulations can also be used to estimate the BB contribution to secondary organic aerosols (SOA), which can be difficult to determine through measurements alone, because of the similarity in chemical characteristics of SOA of BB origin (BBSOA) and SOA from other sources. In addition, there are very few modeling efforts that quantify and assess the BB impact on EC in the MCMA. Finally, to date few studies have assessed the impact of trash burning (TB) on carbonaceous aerosols, which is an important but poorly quantified source of $\mathrm{PM}_{2.5}$ in Mexico City and broader scales (Christian et al., 2010; Hodzic et al., 2012), and is also a major source of particulate chloride in the MCMA ( $\mathrm{Li}$ et al., 2012).

In this study, we employ WRF-CHEM to evaluate the influence of biomass burning on air quality in Mexico City both on the local and regional scales during MILAGRO, with an emphasis on fine carbonaceous aerosols and ozone. The emissions from open BB fires and TB are considered in the model since trash (or garbage) also contains a lot of biomass. The contributions of open fires and TB to OA and EC are apportioned. Additional analyses of the TB impacts on total $\mathrm{PM}_{2.5}$ and chloride are addressed in a companion paper (Li et al., 2012). Since the emissions from domestic and industrial use of biomass may be substantial (Christian et al., 2010; Yokelson et al., 2011) and will be considered in future modeling studies, we only attempt a first-order estimation of their impacts, although the emissions of the domestic and industrial biofuel use are not available yet. Section 2 describes the methodology used in this study; Sect. 3 presents and dis- cusses the results; Sect. 4 estimates the overall BB impacts during March 2006 and on the annual basis, the impacts from the biofuel use, and also discusses the impacts of BB emissions on air quality studies and implications for prescribed fire management; Sect. 5 summarizes this study.

\section{Methodology}

\section{$2.1 \quad$ WRF-CHEM model}

In this study, we apply an updated version of WRF-CHEM (Grell et al., 2005; Tie et al., 2007) to investigate biomass burning impacts. This version was developed at the Molina Center for Energy and the Environment (Li et al., 2010, 2011). Briefly, the modifications include a new flexible gas phase chemistry module, an accurate and efficient gas-phase chemistry solver, the online Fast Tropospheric Ultraviolet and Visible (FTUV) Radiation for photolysis rate calculation, and an aerosol module based on the EPA CMAQ (version 4.6) aerosol module (Binkowski and Roselle, 2003). In this aerosol model, the most recent advances in our understanding of SOA formation and processing are incorporated, including updated (Ng et al., 2007) and $\mathrm{NO}_{\mathrm{x}}$-dependent (Lane et al., 2008b) SOA yields, the volatility-basis set approach (Robinson et al., 2007; Lane et al., 2008a; Tsimpidi et al., 2010), and the oxidation hypothesis of semivolatile and intermediate volatile organic compounds (S/I VOCs) by Grieshop et al. (2009). In addition, heterogeneous HONO sources, which are important in Mexico City, are also parameterized and included in the model (Li et al., 2010). Details of the modifications are described in $\mathrm{Li}$ et al. $(2010,2011)$. 


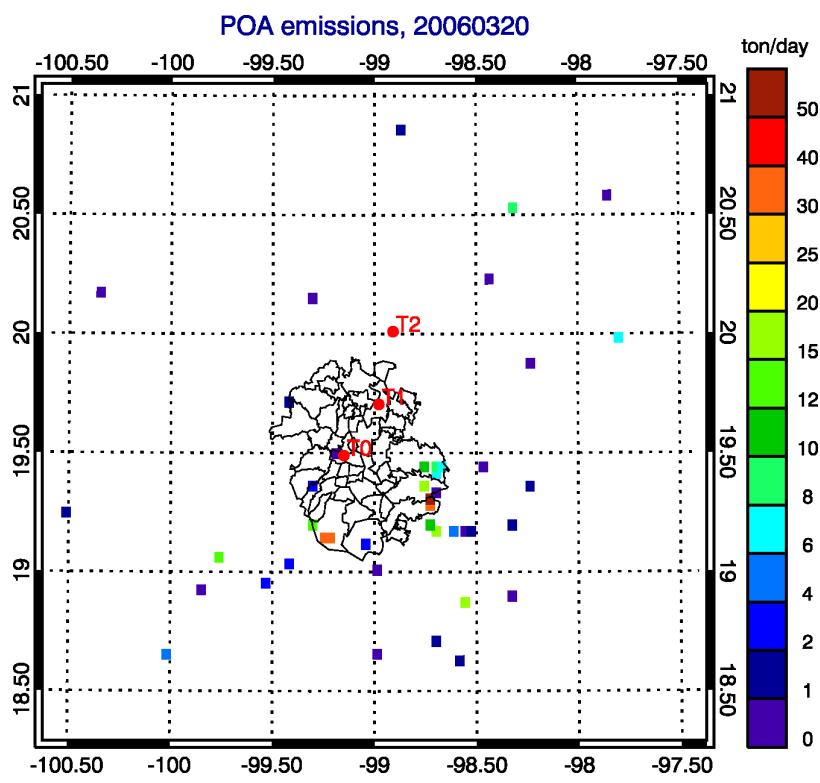

Fig. 1. Model domain and the geographical distribution of forest fire emissions of POA on 20 March 2006 in the domain. The curves are the MCMA delegation political borderlines. The MILAGRO supersites $\mathrm{T} 0, \mathrm{~T} 1$ and $\mathrm{T} 2$ are indicated as dots.

\subsubsection{Model configuration}

Two high fire emission periods, 10-14 and 17-21 March 2006, were selected for this study based on the MODIS satellite fire counts, BB emission rates, and the AMS-PMF analysis (Aiken et al., 2010).

The model domain (Fig. 1) covers the MCMA with a $110 \times 100$ grid at $3 \mathrm{~km}$ horizontal resolution and 35 vertical layers extending from the surface to $50 \mathrm{hPa}$ with variable vertical spacing (the first model layer is about $35 \mathrm{~m}$ a.g.l.). The dynamical modeling system uses the Lin microphysics scheme (Lin et al., 1983), the Quasi-Normal Scale Elimination (QNSE) PBL scheme (Sukoriansky et al., 2005), Noah land-surface model (Chen and Dudhia, 2001), Mlawer longwave radiation parameterization (Mlawer et al., 1997), Dudhia shortwave radiation parameterization (Dudhia, 1989), and Kain-Fritsch Cumulus Parameterization (Kain 2004). Meteorological initial and boundary conditions are driven by NCEP $1^{\circ} \times 1^{\circ}$ reanalysis data, and chemical initial and boundary conditions are interpolated from the MOZART 3h output (Horowitz et al., 2003). The SOA boundary conditions in the boundary layer are set to be $1.4 \mu \mathrm{g} \mathrm{m}^{-3}$ according to previous studies conducted in the MCMA (Hodzic et al., 2009; Dzepina et al., 2009). Because fire plumes are usually narrow and their local and regional influences are very sensitive to dispersion and transport, we have tested several PBL schemes and found that the QNSE parameterization was the most suitable PBL scheme with regards to the PBL wind field and transport in this study compared to other options, such as the Yonsei University (YSU) and Mellor-Yamada-Janjic (MYJ) schemes that are commonly used in WRF modeling.

\subsection{Emissions}

The emissions considered in this model include fossil fuel combustion (mobile, area and point sources), open burning of biomass and trash, and biogenic sources. The emissions from domestic and industrial use of biomass may also be substantial (Christian et al., 2010; Yokelson et al., 2011). For example, on the national scale, Yokelson et al. (2011) and Christian et al. (2010) estimated that the biofuel use accounted for about $39 \%$ of primary $\mathrm{PM}_{2.5}$ and $20 \%$ of $\mathrm{NO}_{\mathrm{x}}$ and VOCs emitted from the total BB emissions in 2006. The emissions from domestic and industrial biofuel use (such as food cooking and brick making) are not included in this study, but will be considered in our future modeling studies.

\subsubsection{Fossil fuel combustion}

The fossil fuel emissions are defined loosely as anthropogenic emissions, and these two terms will be used interchangeably in this study (note that in some studies the biofuel use is included in anthropogenic emissions, e.g., Bond et al. (2004)). The fossil fuel emissions were constructed from the official emission inventory (EI) for the year 2006 for the MCMA and were adjusted based on field campaign measurements and the MCMA air quality monitoring network (RAMA) observations (Song et al., 2010). The emissions outside of the MCMA were a combination of the official regional emission inventory for point sources and an extrapolation of the MCMA emissions scaled to the population distribution for the mobile and area sources. The emission rates of gaseous species were similar to those in Song et al. (2010), except that we have applied an additional factor of 1.4 to increase the emissions rates of higher aromatics (ARO2) given in Song et al., because in their study the emission rates of $\mathrm{ARO} 2$ remained underestimated after their adjustments.

Primary organic aerosols are semi-volatile and undergo gas-particle partitioning under ambient atmospheric conditions. The evaporated portion of emitted POA particles are traditionally not included in any POA emission inventories (because they are not measured or detected under ambient conditions). In order to simulate OA using the volatility basis-set approach, the primary organic emissions must include the emitted primary organic aerosols (volatile and non-volatile) before their dilution in the atmosphere. Under the ambient conditions in Mexico City, following Tsimpdi et al. (2010), the amount of semivolatile VOCs (SVOCs) was estimated to be 2 times the particle-phase (non-volatile) POA emitted (the latter is the quantity reported in traditional emission inventories). In addition, the co-emitted intermediate VOCs (IVOCs) (but are never in particle phase) were assumed to be equivalent to 1.5 times the primary 


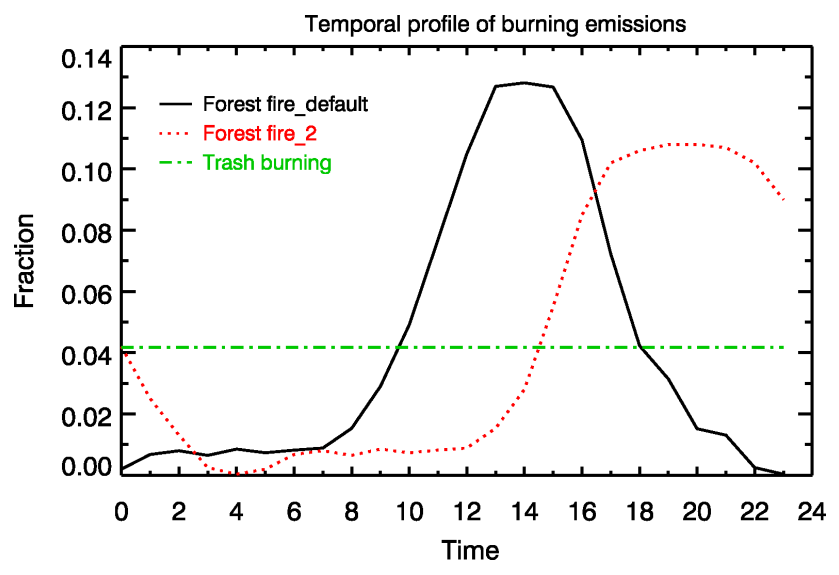

Fig. 2. Diurnal profiles of emissions from forest fire and garbage burning.

organic aerosols actually emitted (i.e., particle-phase POA + SVOCs). The total amount of material (particle-phase POA + SVOC + IVOC) introduced to the model is then 7.5 times the particle-phase POA emissions that are not corrected for the dilution effect (Robinson et al., 2007). Details of the POA emission modification are described in Tsimpdi et al. (2010) and Li et al. (2011).

\subsubsection{Open fires}

The biomass burning emissions considered in this study are those from open fires surrounding Mexico City (dominantly forest fires) and the trash burning. A product of $1 \mathrm{~km} \times 1 \mathrm{~km}$ for the open fire daily emissions of trace gases and particles was developed following the method described by Wiedinmyer et al. $(2006,2011)$. The emissions model applied emission factors (EF) from literature (e.g., Andreae and Merlet, 2001; Akagi et al., 2011), with updates from measurements during the MILAGRO campaign (Yokelson et al., 2007), and used MODIS fire detection data (fire location and timing) (http://maps.geog.umd.edu; Davies et al., 2009). The uncertainty for the fire emissions calculated through this approach is about a factor of 2, which arises from the use of fire hot spots, assumed area burned, land cover maps, biomass consumption estimates, and emission factors. A preliminary version of the open fire emissions calculated above (beta version) has been used by Fast et al. (2009) to evaluate the BB impacts on POA in the MCMA.

The daily emissions were temporally resolved to hourly emissions using satellite fire count-based diurnal profiles. A default diurnal profile ( profile_default) was applied to almost all fires, which was calculated statistically from all fires in the North America subtropical areas in the spring 2003 using the 2003 GOES satellite fire counts (C. Wiedinmyer, personal communication, 2010). In addition, an alternative diurnal profile ( profile_2), in which emissions started later and continued into the night time, was applied to account for the effects of some smoldering fires not detected by satellite observations. There are an infinite number of possible diurnal profiles and the actual diurnal profile is not only unknown, but likely varies from day to day and from fire to fire. We tried a reasonable number of options and ultimately implemented the one that performed best (profile_2) in this study. This alternative profile is similar to the one used by Aiken et al. (2010), which was obtained by limiting fires to higher GOES quality data assurance and yielded a better model measurement agreement for the fire signals during the entire March 2006. The fire onset time in the profile 2 also coincidentally agreed well with aircraft observations in Mexico (Yokelson et al., 2007). This does not imply that the actual profile has been identified. However, our findings do imply that smoldering in the evening may contribute significantly to ground-level impacts in the MCMA. Figure 2 shows the two sets of diurnal profiles. With regard to the release altitude of the open fires, for the majority of the fires, the emissions were allocated evenly in the 2nd and 3rd model layers (up to $250 \mathrm{~m}$ ), while the emissions of smoldering fires were mostly released in the 1 st model layer $(90 \%)$. The reason for a lower release height of the smoldering fires is because these fires usually have smaller flames and continue to emit at night when their emissions are usually trapped in the shallow nocturnal boundary layer. More detailed information on the use of the diurnal profile and the release height of fire emissions is presented in Sect. 3.1.2.

The emissions of SVOCs and IVOCs from the open fires and trash burning were treated similarly as those in the anthropogenic sources (scaling wise) in this study.

\subsubsection{Trash burning}

The trash burning emissions in the MCMA were estimated based on the garbage fire emissions factors measured during MILAGRO (Christian et al., 2010) and the literature (Lemieux et al., 2004; Akagi et al., 2011), in conjunction with a $1 \mathrm{~km} \times 1 \mathrm{~km}$ spatial distribution of population and socioeconomic classifications in Mexico City (Hodzic et al., 2012). In this estimation, the daily per capita trash production and percentage trash burned for different socioeconomic classes was assumed following Ojeda-Benítez et al. (2008). The uncertainty in the estimated TB emissions is about a factor of 2 or more. We also assume that the trash burning emissions are time invariant, since no temporal information is available. This is an approximate first-order assumption and needs to be improved through future observational data or model-measurement comparisons of trash burning molecular markers, such as multiple metals pertinent to TB as proposed by Christian et al. (2010) for Mexico City.

The TB emissions outside the MCMA are not available and are not included in this study. Therefore it should be noted that the estimation of the TB impact will only be restricted to the MCMA, and the model-estimated "regional" 

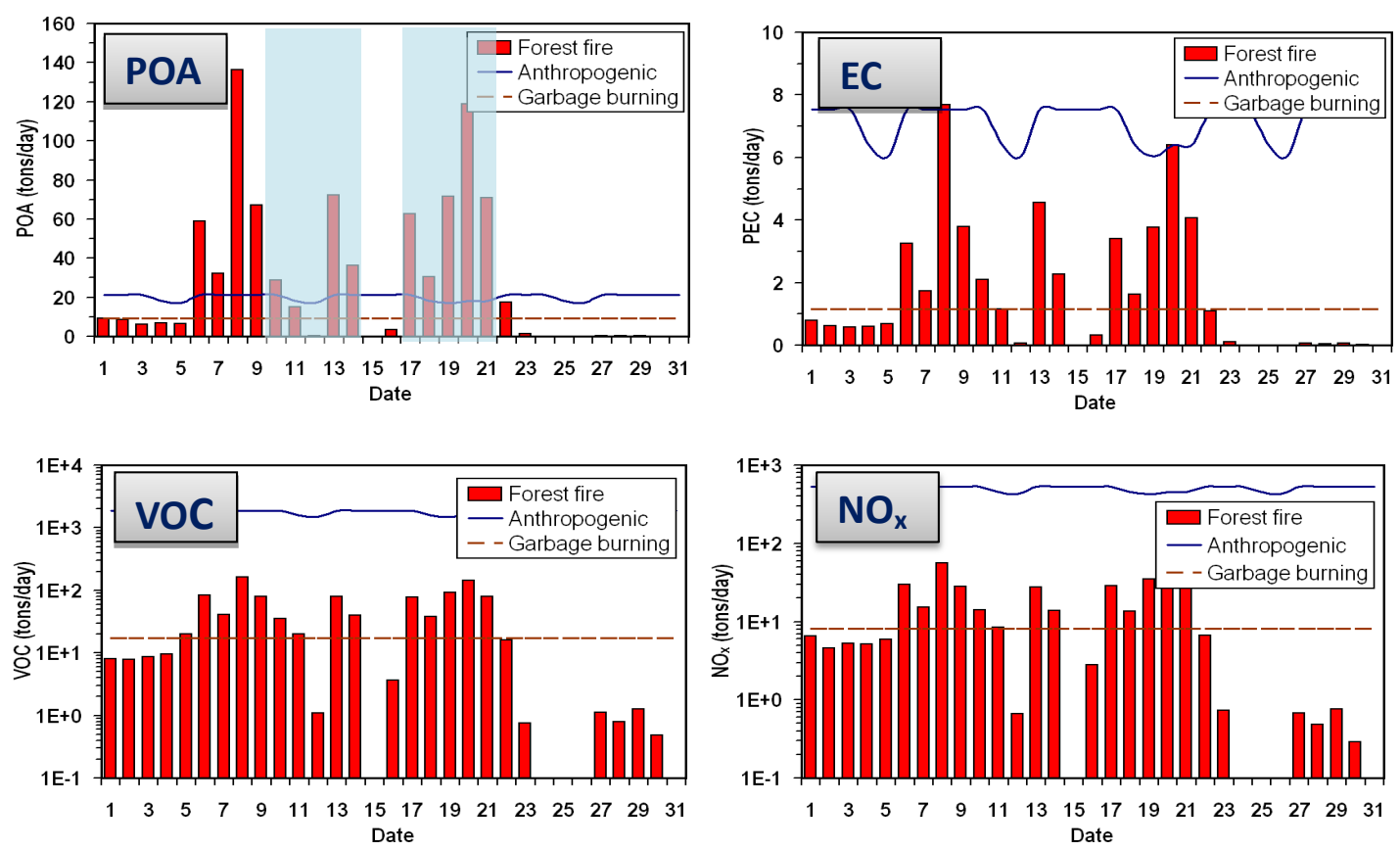

Fig. 3. Emissions of anthropogenic sources, open fires and trash burning in the MCMA during the MILAGRO campaign. The red bars denote the daily emissions of open fires (dominantly forest fires), the blue line denotes the emissions from the fossil fuel use, and the brown dash line denotes the garbage burning emissions. The blue bars indicate the simulation periods.

impact of TB is in fact the influence of the MCMA TB emissions on the regional environment.

\subsubsection{Further discussions on emission}

The daily emissions from the adjusted anthropogenic sources (fossil fuel combustion), open fires and trash burning in the MCMA during MILAGRO are presented in Fig. 3; the domain-wide average daily emissions from these sources during the entire MILAGRO and simulation period are shown in Table 2. It should be noted that the emission estimates in all source categories in the table contain significant uncertainties, although great efforts have been made to minimize the uncertainties. Compared to the anthropogenic emissions we have estimated based on the MCMA-2006 emission inventory (Song et al., 2010), both in the MCMA and the model domain-wide, biomass burning is a minor source for $\mathrm{CO}$, VOCs and $\mathrm{NO}_{\mathrm{x}}$ (less than $10 \%$ ). In contrast, open fires are the major source for POA in the MCMA and domainwide during the dry season (130 and $170 \%$ relative to the anthropogenic emissions, respectively, and even higher during the simulation period), and the open fire contribution is highly variable with time. In the high fire events, open fires dominate the anthropogenic sources, accounting for 3-6 times of the anthropogenic emissions for POA. Trash burning contributes to the emissions of POA at about $45 \%$ of the anthropogenic counterpart in the MCMA and $15 \%$ domainwide. The contribution to the EC emissions from the open fires is also highly variable with an average of $22 \%$ of the anthropogenic sources in the MCMA (27\% domain-wide), which is less significant compared to POA. Garbage burning contributed about $15 \%$ as much EC as the anthropogenic sources in the MCMA.

As pointed out earlier, there exist significant uncertainties in the BB emissions, particularly for VOC emissions from the open fires. These uncertainties comes from biases in the satellite hot spots data, assumed area burned, land cover maps, cloudiness, biomass consumption estimates, and emission factors (because the BB VOC emissions are generated by multiplying the estimated biomass burned times the emission factors (EF) for the VOC species that were measured by the available instrumentation). For example, the majority of fires with small size and short duration in the tropics are not detected. Field and laboratory measurements can only identify about $50 \%$ of the mass of the nonmethane organic compounds emitted from biomass burning due to the instrumentation (Akagi et al., 2011; Yokelson et al., 2011, 2013), and most of the unmeasured VOC are high-mass, reactive compounds. The $\mathrm{BB} \mathrm{VOC} / \mathrm{CO}$ ratios in the emission estimates in the MCMA (and surrounding areas) are about $10 \%$ (see Table 2), which is significantly smaller than the value of $\sim 30 \%$ obtained from aircraft measurements during the MILAGRO campaign (Yokelson et al., 2007; Crouse et al., 2009). The domain-wide BB VOC/CO ratio is even smaller $(\sim 5 \%)$, significantly lower than the global average of 20-40\% (Andreae, 1991; Andreae and Merlet, 2001; Akagi et al., 2011), although it is expected a 
lower-than-global average in Central Mexico. Although MILAGRO studies tended to indicate that BB exerts higher impacts aloft than in the surface (see Table 1), the much lower $\mathrm{BB} \mathrm{VOC} / \mathrm{CO}$ ratio may suggest that BB emissions of VOCs and other species be underestimated. Although a scaling factor has been used in the BB primary organic emissions to indirectly compensate for the VOC underestimation, an underestimation in the $\mathrm{BB}$ emissions still likely exists. Additional uncertainties in the $\mathrm{BB}$ emissions come from the use of assumed diurnal profiles and the fire smoke injection altitude. We used a temporal resolution that best performed for this study, but it does not necessarily imply that the diurnal profile used is accurate. We assumed different fire smoke release heights, depending on whether the fires are flaming or smoldering. Less smokes injected onto lower altitudes or more smokes injected onto higher altitudes may result in same ground impacts. Considering that geographical characteristics (valley floor) along with the emission uncertainties, ground measurements of $\mathrm{BB}$ data at $\mathrm{T} 0$ and $\mathrm{T} 1$ are not ideal for the BB emission constraint due to the "touch down" characteristics of the open fire impact. Both the missing fires and stronger BB impacts aloft may contribute the BB emission uncertainties. Aircraft measurements tracking the smoke plume, which are not included in this study, would help to clarify and assess the BB emissions uncertainties.

These uncertainties in the emissions and the sensitivity of the BB impact to meteorological conditions affect modeling analysis and thus make the modeling study difficult. Despite these, modeling studies offer an independent approach to assess the BB impact on a wider temporal and spatial coverage, and provide important information to evaluate the BB emission inventory, although the latter is not a main objective of this study.

\subsection{Measurements}

The simulated OA concentrations are compared with the MILAGRO High-Resolution Aerosol Mass Spectrometer (AMS) OA measurements at the urban (T0) and the suburban (T1) supersites (Molina et al., 2010). The "measured" biomass burning OA (BBOA) component was derived from the Positive Matrix Factorization (PMF) analysis of the AMS data (Aiken et al., 2009, 2010). The overall uncertainty in the AMS measurement is estimated to be $35 \%$ (Bahreini et al., 2009), and the uncertainty in the PMF analysis comes from the uncertainty in the measurement data and the ambiguity of the PMF solutions (Ulbrich et al., 2009). AMS-PMF analysis also identifies hydrocarbon-like OA (HOA) and oxygenated OA (OOA, mostly secondary OA or SOA). Note that the AMS-PMF BBOA is dominantly the primary organic aerosol (POA), and BB SOA is included in OOA due to similar spectra of the two.

Simulated particulate EC concentrations are compared with the EC data measured using an Aethalometer and an aerosol absorption photometer at T0 and T1 (Marley et al.,
Table 2. Emission averages (tons/day) from different sources in the model domain during MILAGRO in March and during the simulation periods.

\begin{tabular}{lccccc}
\hline & \multicolumn{5}{c}{ March 2006} \\
\cline { 2 - 6 } & $\mathrm{CO}$ & $\mathrm{VOCs}^{\mathrm{a}}$ & $\mathrm{NO}_{\mathrm{x}}$ & $\mathrm{POA}^{\mathrm{b}}$ & $\mathrm{EC}$ \\
\hline Anthropogenic & 15017.0 & 4543.6 & 1465.1 & 69.4 & 27.3 \\
Open fire & 1477.1 & 153.4 & 61.2 & 119.6 & 7.4 \\
Trash burning & 92.3 & 20.0 & 9.4 & 10.8 & 1.3 \\
\hline \multicolumn{7}{c}{ During the simulation periods } \\
\hline Anthropogenic & 13515.2 & 4089.2 & 1318.6 & 62.4 & 24.6 \\
Open fire & 2562.9 & 282.4 & 105.3 & 203.5 & 12.0 \\
Trash burning & & & & \\
\hline
\end{tabular}

${ }^{\text {a }}$ SVOCs and IVOCs from or co-emitted with semivolatile POA emissions are not included.

$\mathrm{b}$ particle-phase.

$c$ not TB emissions outside the MCMA.

2009a, b). Simulated $\mathrm{CO}$ and $\mathrm{O}_{3}$ concentrations are compared with the measurements from the RAMA ambient air quality monitoring stations.

\subsection{Estimation of the simulated BB impacts}

The BB impacts are calculated by conducting simulations with and without BB emissions. The difference in the scenarios with and without the $\mathrm{BB}$ emissions is attributed to BB. Contributions from a specific burning type, such as open fires and trash burning, are estimated using similar method. The percentage change is the difference relative to the scenario with all emissions included.

\section{Results and discussions}

\subsection{Model performance}

\subsubsection{Carbon monoxide and ozone}

Figure 4 shows the comparisons of measured and simulated near surface $\mathrm{CO}$ and $\mathrm{O}_{3}$ hourly concentrations averaged over the RAMA stations (about 18 stations with available observation data during the simulation periods with majority located in the urban area), and Table 3 presents the statistical performance for $\mathrm{O}_{3}, \mathrm{CO}$ and carbonaceous aerosols. In the simulations, the biomass burning emissions are included. During the two 5-day episodes, in general the model captured the diurnal variations of $\mathrm{CO}$ and $\mathrm{O}_{3}$ reasonably well, with the index of agreement (IOA) reaching 0.88 and 0.96 for $\mathrm{CO}$ and $\mathrm{O}_{3}$ respectively. The simulated $\mathrm{CO}$ concentration mean $(1.1 \mathrm{ppm})$ agrees very well with the observation (vs. $1.2 \mathrm{ppm}$ ), implying that both anthropogenic and BB nearsurface emissions were accurately estimated. The days with inferior $\mathrm{O}_{3}$ agreement are usually coincident with the days of inferior CO agreement, such as on 10 and 11 March when 

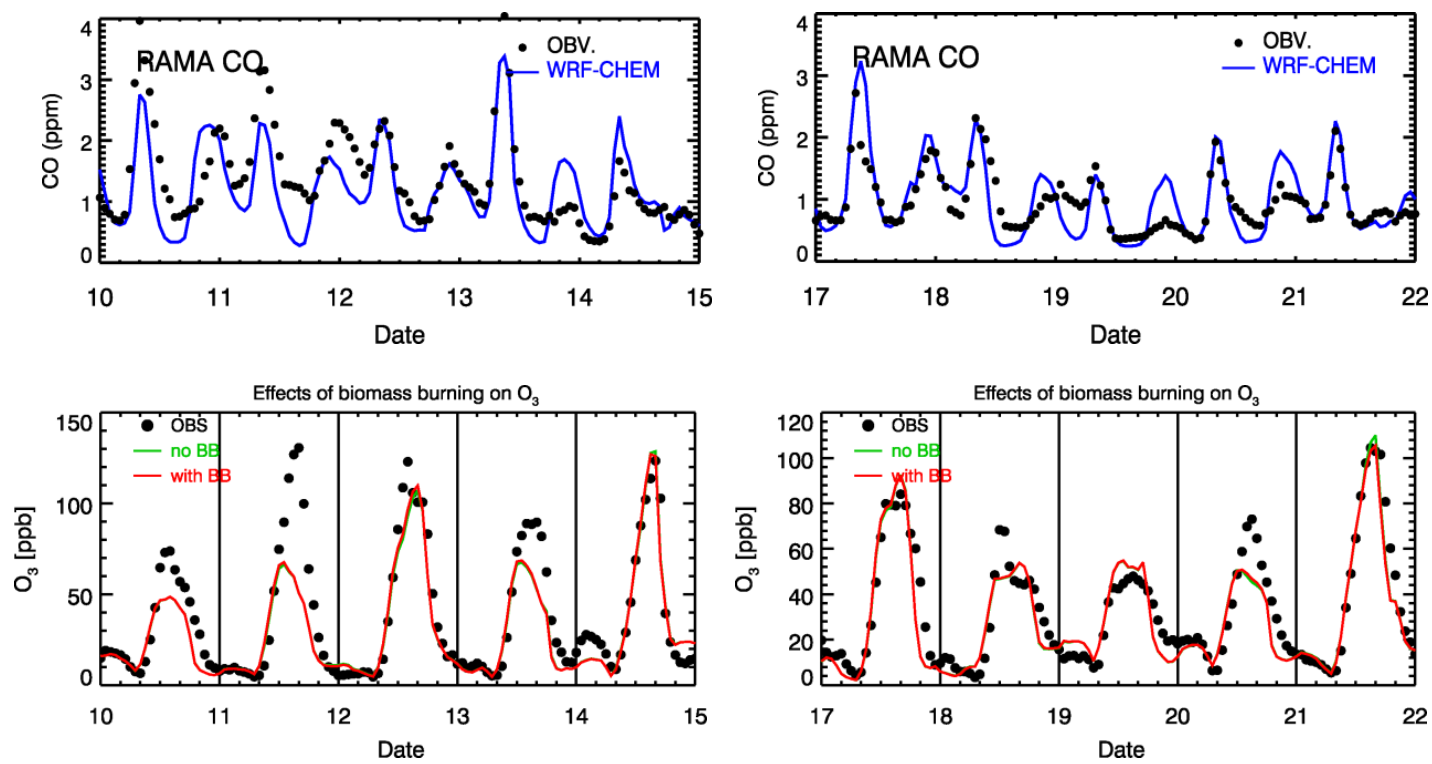

Fig. 4. Comparisons of measured and simulated $\mathrm{CO}$ and $\mathrm{O}_{3}$ averaged over the RAMA stations during 10-14 and 17-21 March 2006. Dots represent observations, and lines represent simulations. Two cases for $\mathrm{O}_{3}$ simulations are presented: excluding $\mathrm{BB}$ (no $\mathrm{BB}$, green lines) and including $\mathrm{BB}$ (with $\mathrm{BB}$, red lines) emissions. Note that because of the small impact of $\mathrm{BB}$ on $\mathrm{O}_{3}$, the green and red lines are almost overlapped most of the time.

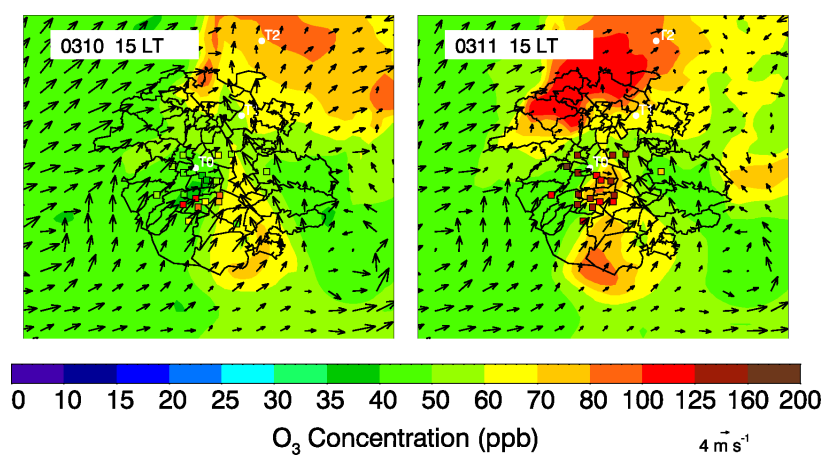

Fig. 5. Spatial distribution of ground $\mathrm{O}_{3}$ concentration at 15:00 LT on 10 and 11 March. Colored squares represented RAMA observations, and colored contour and black arrows are simulated $\mathrm{O}_{3}$ and wind fields, respectively.

both $\mathrm{CO}$ and $\mathrm{O}_{3}$ were under predicted. 10-12 March was an "O $\mathrm{O}_{3}$-North" episode (de Foy et al., 2008) followed by a transition to an " $\mathrm{O}_{3}$-South" episode starting on 15 March. 1821 March was another " $\mathrm{O}_{3}$-North" period. The "O ${ }_{3}$-North" event features a convergence zone that forms inside the basin and proceeds to the north and northeast during the daytime, causing the urban pollution plume to move towards the north and northeast progressively. The under-predictions of $\mathrm{CO}$ and $\mathrm{O}_{3}$ on these two days are probably because the simulated daytime southerly winds were too strong and caused the northward transport to be too fast and too strong, as illustrated in Fig. 5. The four-dimensional data assimilation
(FDDA) technique, not used in this study, could improve the meteorological fields for this episode (Song et al., 2010).

\subsubsection{Primary Organic Aerosol from Biomass Burning (BBPOA)}

The PMF-derived AMS BBOA is mainly primary BBOA (BBPOA), with the SOA produced from the BB activities (BBSOA) detected mostly as OOA (oxygenated OA). Figure 6 shows the comparison of the PMF-AMS and simulated BBPOA at T0 during 10-14 March and at T0 and T1 during 17-21 March (there were no PMF-AMS data at T1 before March 14). Two emission scenarios are presented in the simulation - "default" and "adj". In the "default" scenario, the default diurnal profile was used for all open fires (see Fig. 2). In the "adj" simulation for the episode of 10-14 March, the profile_2 was used for the fires located south of T0 within $60 \mathrm{~km}$ on 10-11 March. In the "adj" simulation for the episode of 17-21 March, the profile_2 was applied to the open fires located in the southeast of T0 within $60 \mathrm{~km}$ on 17 March, the fires in the south of T0 within $60 \mathrm{~km}$ on March 18 , and three large fires in the southwest close to T0 on 2021 March. The fires with the profile 2 diurnal profile were distributed in the model's bottom layer; all other fires were distributed in the 2 nd and $3 \mathrm{rd}$ model layers. The rationales for the adjustment of the diurnal profile of sectional or individual fires were based on the evening-nighttime transport conditions, fire locations and their potential direct hits at $\mathrm{T} 0$ (as will be shown later in Figs. 7 and 8). The range of $60 \mathrm{~km}$ was chosen based on Aiken et al. (2010) who found that the 
Table 3. Statistical measures of model performance during the two simulated episodes.

\begin{tabular}{lccccccc}
\hline & $\mathrm{O}_{3}^{\mathrm{a}}$ & $\mathrm{CO}$ & BBPOA $^{\mathrm{c}}$ & POA & SOA & \multicolumn{2}{c}{ EC } \\
\cline { 2 - 8 } & RAMA & RAMA & T0 & T0 & T0 & T0 & T1 \\
\hline Mean obs $^{\mathrm{b}}$ & 71.2 & 1.18 & 4.4 & 10.0 & 6.9 & 4.2 & 2.4 \\
Mean mod $^{\mathrm{b}}$ & 60.1 & 1.09 & $3.2(2.3)$ & 8.3 & 8.2 & 4.3 & 1.4 \\
RMSE $^{\mathrm{b}}$ & 21.1 & 0.46 & $5.2(5.9)$ & 8.5 & 6.1 & 2.6 & 2.1 \\
NB $(\%)$ & -13.7 & -2.7 & $1.6(-10.4)$ & 3.6 & 43.3 & 11.7 & -21.3 \\
NMB (\%) & -15.7 & -7.3 & $-28.5(-48.5)$ & -17.5 & 18.6 & 0.10 & -41.5 \\
IOA & 0.92 & 0.88 & $0.60(0.37)$ & 0.70 & 0.66 & 0.76 & 0.53 \\
\hline
\end{tabular}

${ }^{a}$ The cutoff (threshold) concentration for $\mathrm{O}_{3}$ was set at $40 \mathrm{ppb}$ in the statistical calculations.

$\mathrm{b}$ the units are $\mathrm{ppb}$ for $\mathrm{O}_{3}$, ppm for $\mathrm{CO}$, and $\mu \mathrm{g} \mathrm{m}^{-3}$ for $\mathrm{PM}$.

$c$ numbers in the parenthesis are for the case where the default BB emissions are used, BBPOA is a fraction of POA.

Note: obs $=$ observation, $\bmod =$ model, $\operatorname{RMSE}($ root mean suqare root $)=\left[\frac{1}{N} \sum_{i=1}^{N}\left(P_{i}-O_{i}\right)^{2}\right]^{\frac{1}{2}}$,

$\mathrm{NB}($ normalized bias $)=\frac{1}{N} \sum_{i=}^{N} \frac{\left(P_{i}-O_{i}\right)}{O_{i}} \times 100 \%$,

NMB (normalized mean bias $)=\frac{\sum_{i=1}^{N}\left(P_{i}-O_{i}\right)}{\sum_{i=1}^{N} o_{i}} \times 100 \%$,

IOA (index of agreement) $=1-\frac{\sum_{i=1}^{N}\left(P_{i}-O_{i}\right)^{2}}{\sum_{i=1}^{N}\left(\left|P_{i}-\bar{O}\right|+\left|O_{i}-\bar{O}\right|\right)^{2}}$, where $\mathrm{O}_{i}$ and $\mathrm{P}_{i}$ are observed and predicted
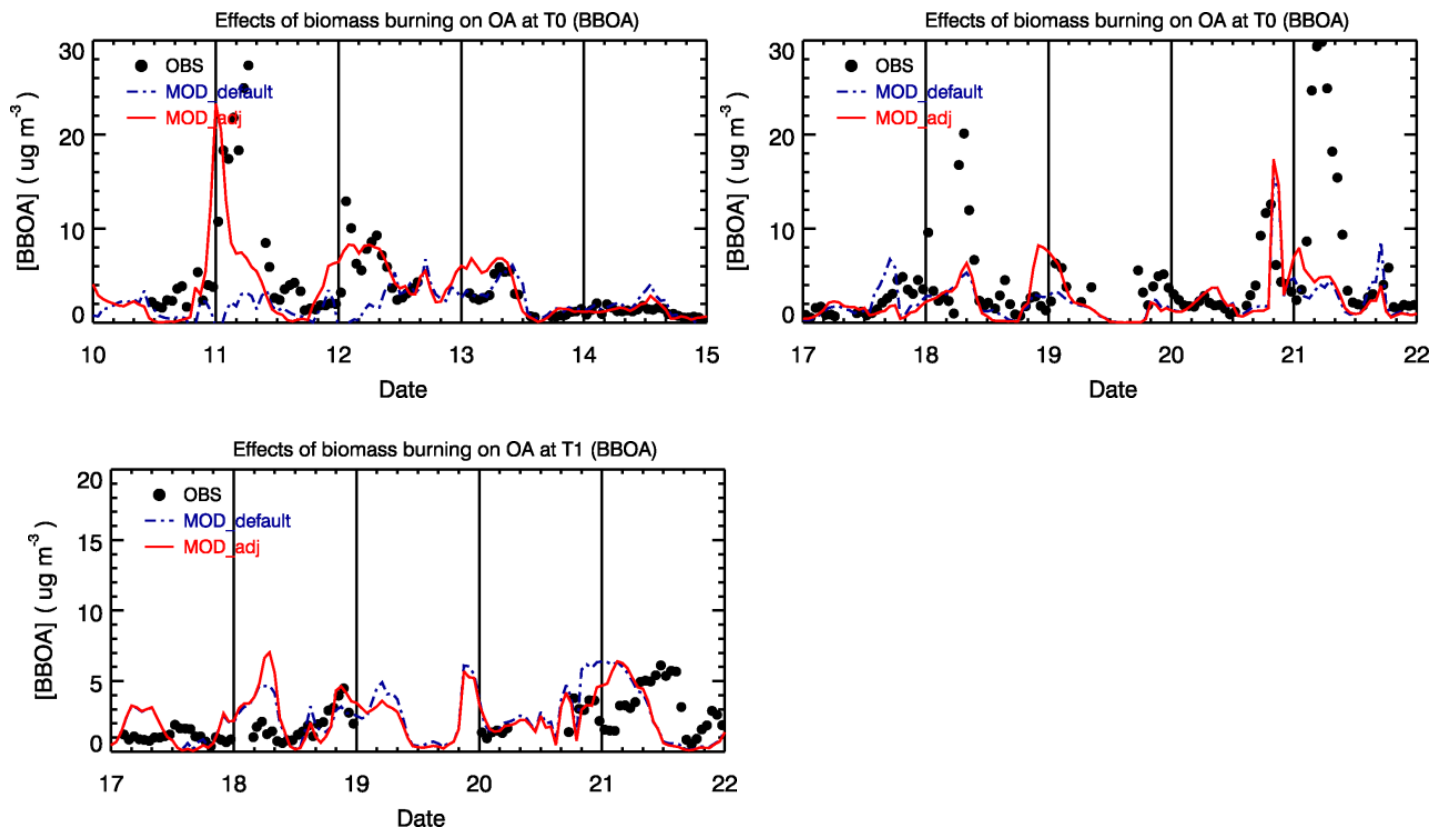

Fig. 6. Comparisons of AMS-derived and simulated BBPOA concentrations at T0 during 10-14 March and at T0 and T1 during 17-21 March. The black dots represent AMS PMF data, the dashed blue lines represent the simulations with the default BB emissions, and the red lines represent the simulations with the adjusted BB emissions. Details of the BB emissions are described in the main text.

open fires within $60 \mathrm{~km}$ of $\mathrm{T} 0$ dominated the BB influences to $\mathrm{T} 0$. We have conducted several additional scenarios to examine the sensitivity of the simulated BB impacts at $\mathrm{T} 0$ and $\mathrm{T} 1$ to the BB diurnal profile, smoke injection altitude, and trans- port condition (through different PBL schemes); we found that the simulated BB impacts at specific locations were most sensitive to meteorology, quite sensitive to the diurnal profile, but least sensitive to the daytime injection altitude. The 

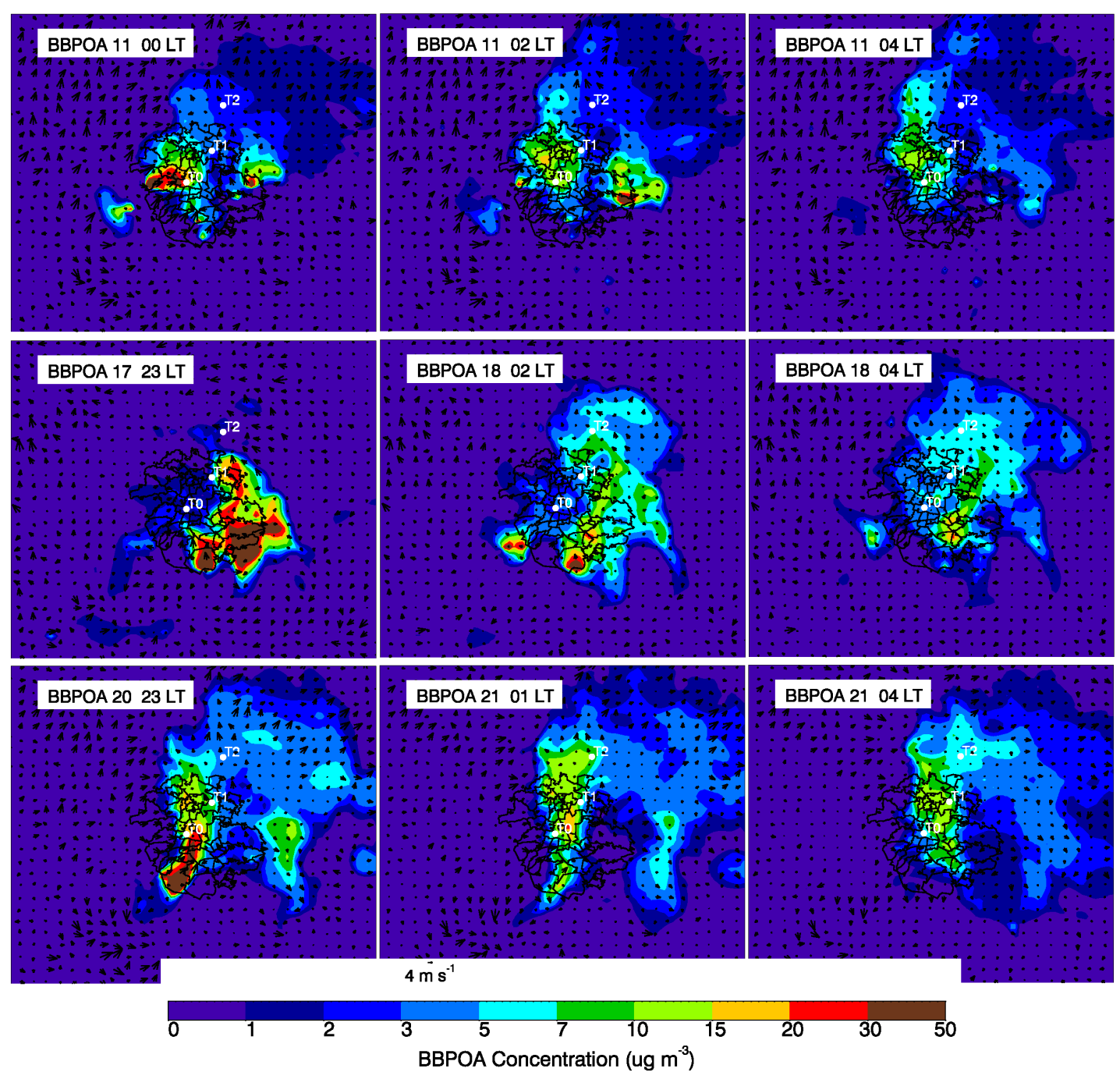

Fig. 7. Simulated BBPOA spatial distributions and their evolutions at nighttime. The date and local time is shown in the caption (e.g., 1102 LT means 11 March 02 a.m.).

injection altitude of daytime fires was limited to the lowest three model layers in the sensitivity tests. The sensitivity (to the injection altitude) could be different if the injection altitude is extended to the entire boundary layer.

Figure 6 shows that with the adjusted BB emissions, the model captures both the magnitude and temporal variation of the BBPOA ambient concentrations at T0 quite well, particularly during 10-14 March. During this period, the AMS BBOA concentrations started at very high levels on 11 March $\left(\sim 28 \mu \mathrm{g} \mathrm{m}^{-3}\right.$, all concentrations are referred to as those under the ambient conditions) and decreased progressively with time and very low BB effects were found on 14 March; the inter-diurnal variation is well captured by the model. It is noticeable, from Fig. 6 and Table 3, that both the magnitude and time variation of the simulated BBPOA improved significantly when the adjusted $\mathrm{BB}$ emissions were used (compared to the default BB emissions). The simulated BBPOA was highly variable temporally, ranging between as low as a few tenth $\mu \mathrm{g} \mathrm{m}^{-3}$ and as high as over $20 \mu \mathrm{g} \mathrm{m}^{-3}$. BBPOA was observed generally high in the early morning, decreased during the daytime when the mixing and transport became stronger, and started to accumulate at late evening when the afternoon emissions increased and the nocturnal PBL set in. This diurnal variation is also well captured by the model, although there are some biases in the exact timing. On March 11 , a very high BBPOA peak was observed in the early morning, but the model precedes the peak by about $4-5 \mathrm{~h}$, probably due to rapid transport in the model. During 17-21 March, the model captures reasonably well the diurnal and interdiurnal variability of the BBPOA. Except for the two extremely high early morning BBPOA peaks detected by the AMS on March 18 and $21\left(\sim 20\right.$ and $\left.30 \mu \mathrm{g} \mathrm{m}^{-3}\right)$, the model simulates reasonably well the BBPOA concentrations and the diurnal variation at $\mathrm{T} 0$, with the IOA of 0.60 (see Table 3) 

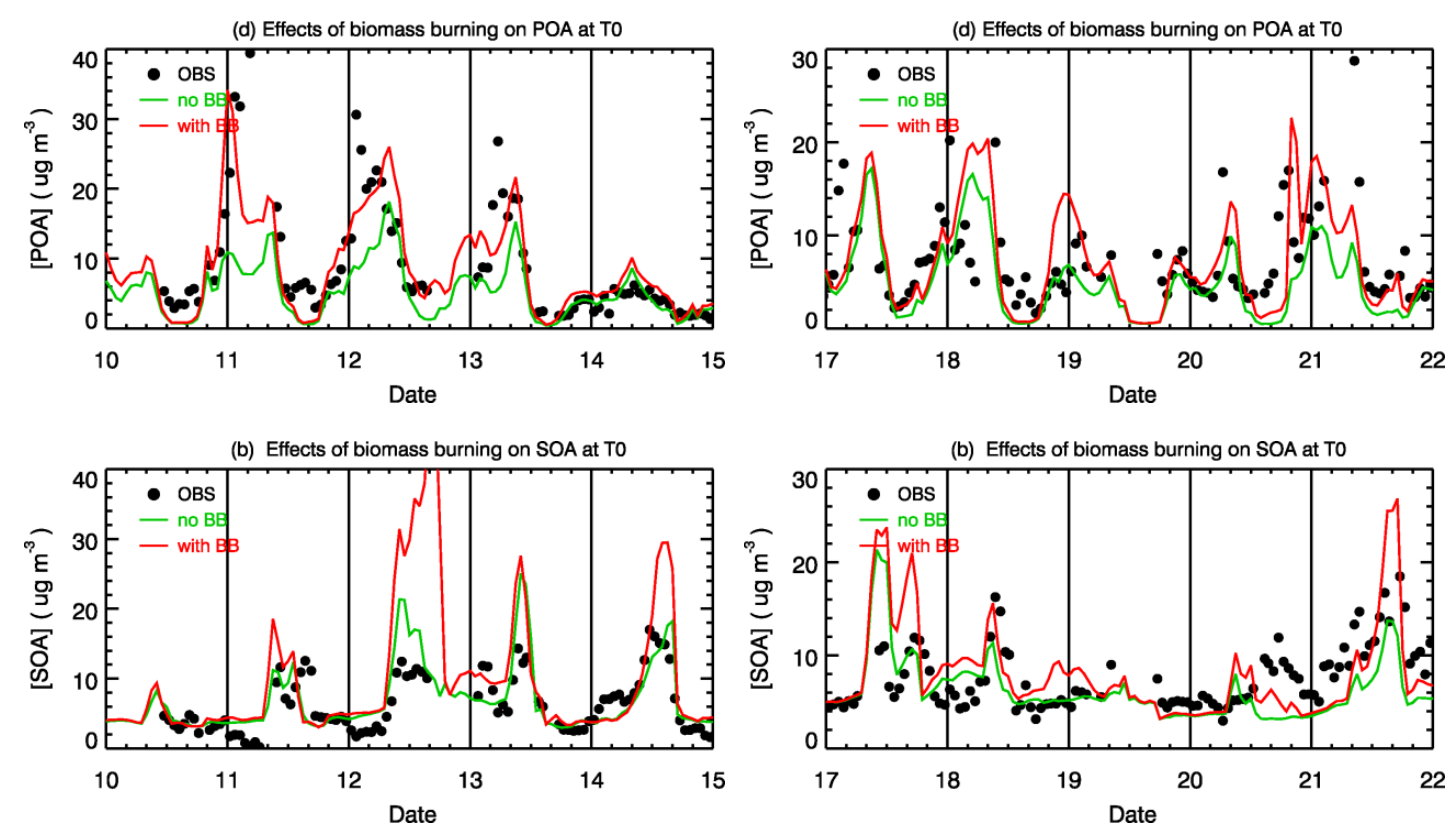

Fig. 8. Comparisons of observed and simulated POA (top panels) and SOA (bottom panels) at T0. Green lines denote the case without the $\mathrm{BB}$ emissions, while red lines denote the case with the BB emissions.

and a model's underprediction of $28 \%$ (average concentrations of $4.4 \mu \mathrm{g} \mathrm{m}^{-3}$ in observations vs. $3.2 \mu \mathrm{g} \mathrm{m}^{-3}$ in simulations during the simulation episodes). We also note that there is a significant bias in the simulation (with the RMSE value larger than the averages), suggesting a significant uncertainty in the modeling; however, it could also be reflecting the real high variability in the BB activities. The model underprediction could be attributed to the uncertainties in both the AMS and PMF analysis and modeling, and could also be attributed to the fact that some fires were not detected by satellites and were not registered as hotspots (Yokelson et al., 2011). If the two extreme events are removed in the comparison, the average concentrations would become $3.1 \mu \mathrm{g} \mathrm{m}^{-3}$ from observation and $2.8 \mathrm{\mu g} \mathrm{m}^{-3}$ from simulation, and the IOA would improve to 0.76 with the RMSE reducing to $2.8 \mathrm{\mu g} \mathrm{m}^{-3}$. At $\mathrm{T} 1$, the model was able to predict the magnitude of BBPOA concentration, but failed to reproduce the diurnal variability. In addition, there were limited observation data on OA, which makes the comparison more difficult.

Aiken et al. (2010) attributed the two peaks (on 18 and $21 \mathrm{March})$ to the nearby smoldering fire plumes that directly "hit" T0. They applied FLEXPART to estimate the fire impact factor (FIF) and found that using a diurnal profile similar to the profile $\_2$ increased the overall agreement between AMS BBOA and FIF, but the improvement for the 21 March peak was still very limited. We examined these two peaks with various hypothetical diurnal profiles of the BB emissions, and found that only limited improvements can be achieved in reproducing the two observed peaks. Furthermore, whenever the nighttime and early morning BBPOA were better simulated at $\mathrm{T} 0$ using different $\mathrm{BB}$ diurnal profiles, the BBPOA concentrations at $\mathrm{T} 1$ would be significantly overestimated. Simulated spatial distributions of BBPOA and its nighttime evolution, as illustrated in Fig. 7, show that if a BB plume hits $\mathrm{T} 0$ at night, it would also hit $\mathrm{T} 1$ because of the proximity of $\mathrm{T} 0$ and $\mathrm{T} 1$, and the weak but consistent southerly nighttime wind field that confines yet horizontally broadens the nighttime BB plume within the shallow PBL. The observed BBPOA concentrations were not correlated to each other at T0 and T1 (partially due to the time lag between the contaminated air mass hitting T0 and T1), but the simulated BBPOA were correlated to some extent, particularly at night. This discrepancy is probably due to the fact that the satellite-based BB emission inventory may not capture the emissions of some local fires as mentioned above. In addition, Aiken et al. (2010) claimed that the increase of AMS BBOA at 5-8 p.m. on 20 March at T0 was due to the hit of the smoldering fire. Our simulations show that the evening spike of BBPOA on 20 March did not have to be attributed from the smoldering fires (note that the default case was also able to reproduce this spike). If the smoldering fire hit T0 starting at 5-6 p.m. on 20 March, it would most likely remain hitting T0 throughout the nighttime due to the constant weak wind pattern, and would be less likely to circumvent T0 from 8 p.m. -4 a.m. next day and resurge after 4 a.m. without affecting T1. It is probable that some local burnings could contribute to the two extreme early morning peaks on 18 and 21 March. The possible local burnings are less likely from cooking sources, which are an important source for OA (Christian et al., 2010; Mohr et al., 2012) 
Table 4. Observed and simulated concentration ratios of POA/TOA with and without BB emissions at T0 and T1 during the two fire periods.

\begin{tabular}{ccccccc}
\hline Episode & \multicolumn{3}{c}{ POA/TOA at T0 } & \multicolumn{3}{c}{ POA/TOA at T1 } \\
\hline & AMS & $\begin{array}{c}\text { Simulated } \\
\text { No BB }\end{array}$ & $\begin{array}{c}\text { Simulated } \\
\text { With BB }\end{array}$ & AMS & $\begin{array}{c}\text { Simulated } \\
\text { No BB }\end{array}$ & $\begin{array}{c}\text { Simulated } \\
\text { With BB }\end{array}$ \\
\hline 10-14 Mar & $0.54 \pm 0.20$ & $0.43 \pm 0.19$ & $0.47 \pm 0.22$ & NA & $0.16 \pm 0.09$ & $0.31 \pm 0.19$ \\
17-21 Mar & $0.50 \pm 0.17$ & $0.47 \pm 0.21$ & $0.49 \pm 0.23$ & $0.41 \pm 0.12$ & $0.23 \pm 0.14$ & $0.38 \pm 0.22$ \\
\hline Average & $0.52 \pm 0.19$ & $0.45 \pm 0.20$ & $0.48 \pm 0.23$ & NA & $0.20 \pm 0.13$ & $0.34 \pm 0.21$ \\
\hline
\end{tabular}

in the urban areas, but would not exert significant impacts until later hours. However, it cannot be ruled out that meteorology may play a critical role in the occurrence of the two peaks, since the transport and disperse of a BB plume is sensitive to the meteorological conditions. Figure 7 also shows that BBPOA is spatially highly variable, with maximum concentrations occurring near the fire location and its immediate downwind area.

\subsubsection{Primary Organic Aerosol (POA) and Secondary Organic Aerosol (SOA)}

The comparisons of AMS-derived and simulated surface OA concentrations at T0 are shown in Fig. 8. Note that in this comparison, BBPOA is included in POA, since the AMSPMF BBOA is dominantly the primary organic aerosol; the SOA in the measurements is represented by the AMS-PMF OOA component, which is the SOA surrogate. No comparisons at $\mathrm{T} 1$ are presented in this study due to the limited AMS-PMF data available during 10-14 March as mentioned above. For the two episodes (10-14 March and 17-21 March), the POA concentrations and their intra- and interdiurnal variations simulated with the $\mathrm{BB}$ emissions agree well with the observations with the IOA of 0.70 . On the other hand, SOA at T0 tended to be systematically overestimated even without the BB influence (6.9 vs. $8.2 \mu \mathrm{g} \mathrm{m}^{-3}$ in observed and predicted averages, and the IOA of 0.66 ; see Table 3), especially during 10-14 March. The systematic overestimation of SOA (especially when BB was included) but a reasonable prediction of POA is probably associated with inaccurately simulated long range transport. Aged air mass with large fires from distant ranges may be incorrectly simulated to pass over T0. We were also aware that in the SOA simulation, we have assumed that the $\mathrm{OH}$ - initiated oxidations of intermediate and semi-volatile VOCs did not consume $\mathrm{OH}$ assuming that $\mathrm{OH}$ would be recycled at the end, similar to $\mathrm{OH}$ recycling in the VOC gas-phase oxidation processes. The $\mathrm{OH}$ non-consuming aging processes can enhance the daytime SOA formation by more than $10 \%$ (Li et al., 2011). A more reasonable scenario with a partial consumption of $\mathrm{OH}$ in the aging processes could also improve the SOA simulation.

Table 4 summarizes the model performance on the OA simulation in terms of the POA/TOA ratio at T0 and T1 dur- ing the two episodes (the SOA/TOA ratio is not listed, since $\mathrm{SOA} / \mathrm{TOA}=1-\mathrm{POA} / \mathrm{TOA})$. It shows that with the BB influence considered, the partition of POA and SOA is well simulated, with SOA being overestimated. It also shows that, from both measurements and simulations, SOA accounts for about $50 \%$ of TOA at T0, and increases to $60 \%$ at T1, indicating the chemical aging process during the urban plume outflow process. Comparisons of the simulated POA/TOA ratios with and without $\mathrm{BB}$ emissions suggest that the major contribution of $\mathrm{BB}$ to $\mathrm{OA}$ is POA, which is more evident at $\mathrm{T} 1$ (the POA/TOA ratio increasing from 0.23 to 0.38 ), implying that $\mathrm{T} 1$ is affected more by BB primary emissions than the aging process in the fire plume.

\subsubsection{Elemental carbon}

As shown in Fig. 9, the model captured both the magnitude and temporal variations of the EC concentration at T0 very well, except during a few days when the observed EC levels were very high (such as on 10, 11 and 13 March).That EC was well simulated while BBPOA was significantly underestimated at T0 on 18 and 21 March, suggesting the existence of smoldering fires near T0 not detected by the satellite. Other than that, no systematic biases were found; the IOA at T0 is 0.76 (0.73 and 0.79 during $10-14$ and 17-21 March, respectively). On the other hand, EC at T1 was systematically underestimated by about $42 \%$ in the model, especially during the second episode, although the temporal variation was reasonably well predicted. The IOA at T1 is $0.53(0.37$ and 0.66 during the two periods respectively). The underestimation at $\mathrm{T} 1$ could be due to the underestimation of EC emissions from sources other than the open fires and TB in the local and surrounding areas. For instance, Christian et al. (2010) observed high EC emissions from several brick kilns near T1. It could also suggest that the TB emissions near $\mathrm{T} 1$ are higher than estimated in the emission inventory.

\subsection{Evaluation of simulated BB impacts at local and regional scales}

Figures 4, 8, 9 and 10 illustrate the BB impacts on groundlevel $\mathrm{O}_{3}$, POA (including BBPOA), SOA and EC in the MCMA and surrounding areas. Biomass burning has, from this study, negligible effects on the surface $\mathrm{O}_{3}$ concentration 

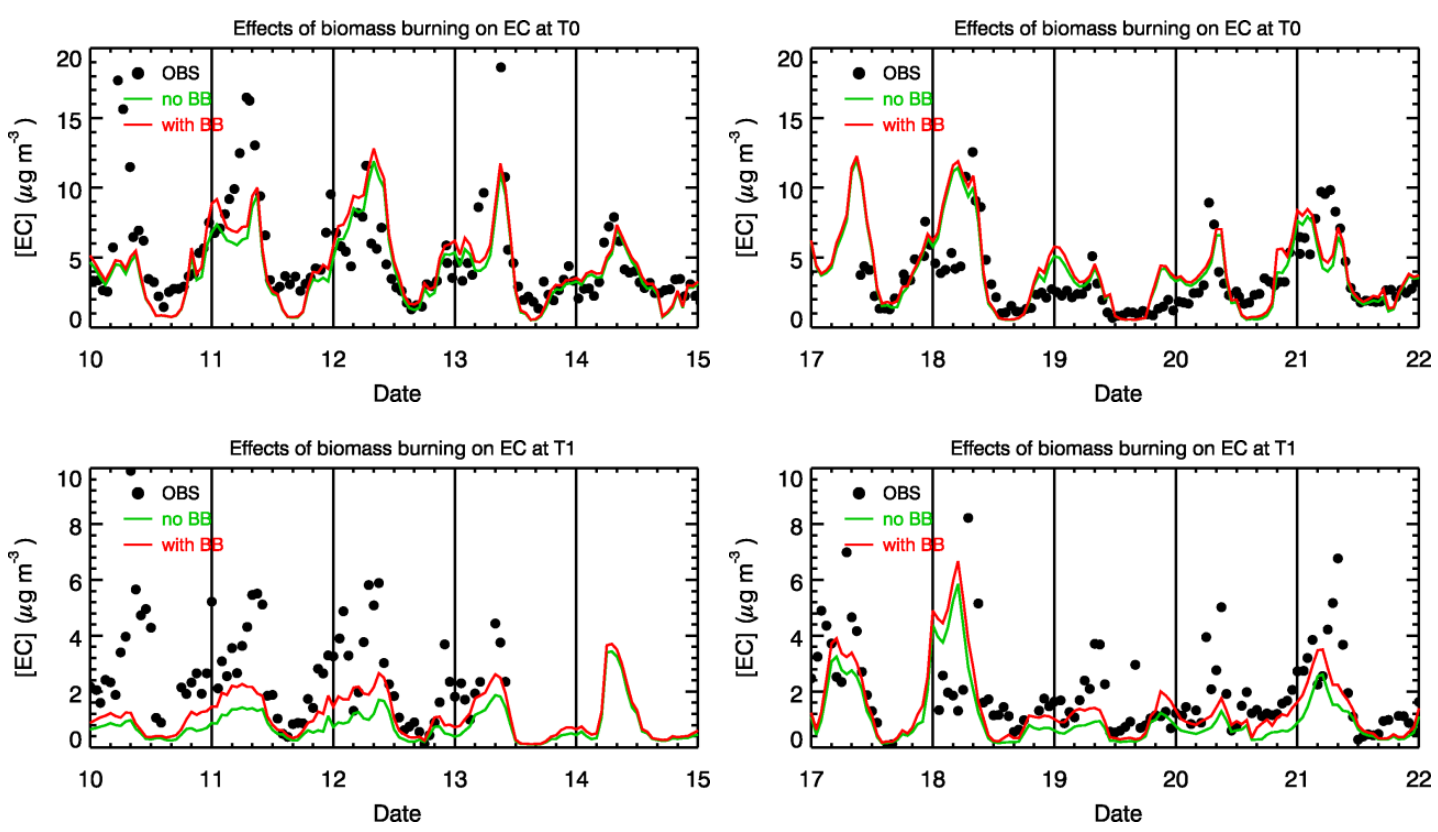

Fig. 9. Comparisons of observed and simulated elemental carbon particulates at $\mathrm{T} 0$ and $\mathrm{T} 1$. The adjusted $\mathrm{BB}$ emissions were used in the simulations.

both in the MCMA urban and suburban areas (with an average of $-0.2 \%$ contribution), due to its comparatively low contribution to total emissions of VOCs and $\mathrm{NO}_{\mathrm{x}}$ (less than $3 \%$ of the total MCMA emissions) and the compensating effects of the emitted aerosol precursors and aerosols on the $\mathrm{O}_{3}$ production. The $\mathrm{BB}$ contribution to $\mathrm{POA}$ is significant, consistently about $33 \%$ at $\mathrm{T} 0$ in the two episodes, and much higher at $\mathrm{T} 1$ of about $63 \%$ (Fig. 10a-b). The BB contributions to SOA are smaller than that to POA, with contributions of $\sim-22 \%$ at both $\mathrm{T} 0$ and $\mathrm{T} 1$. The BB contributions to TOA are about $30 \%$ and $40 \%$ at $\mathrm{T} 0$ and $\mathrm{T} 1$, respectively. Note that important temporal variation exists in all numbers as indicated in the standard deviations. The BB influence on $\mathrm{EC}$ is minor at $\mathrm{T} 0(\sim 9 \%)$, but becomes more important at $\mathrm{T} 1$ $(29 \%)$. However, as noted above, the model underestimation of EC emissions from sources other than the open fires near $\mathrm{T} 1$ probably contributes to this result.

The $\mathrm{BB}$ influences on the surface $\mathrm{O}_{3}$ concentrations are also minor when averaged over the local (MCMA) and regional (model domain) scales. However, the regional $\mathrm{O}_{3}$ impact $(0.2 \%)$ is likely underestimated due to the probable underestimation of the BB VOC emissions discussed earlier. On the other hand, $\mathrm{O}_{3}$ production in the fire plumes are typically $\mathrm{NO}_{\mathbf{x}}$-limited (Jaffe and Widger, 2012), therefore photochemical modeling is needed to examine how the VOC underestimation will affect $\mathrm{O}_{3}$ production. Observations of the excess ratio of $\Delta \mathrm{O}_{3} / \Delta \mathrm{CO}$ in the fire plumes have been used to characterize the $\mathrm{BB} \mathrm{O}_{3}$ production in smoke plumes (Jaffe and Wigder, 2012). Using $\Delta \mathrm{O}_{3} / \Delta C O$ value of 0.15 in aged fires (after several hours) in Central Mexico, and noting the
$10 \%$ contribution of $\mathrm{BB} \mathrm{CO}$ to the anthropogenic $\mathrm{CO}$ emissions (Table 2), we estimate that the $\mathrm{BB}$ contribution to $\mathrm{O}_{3}$ would increase to about $1.5 \%$, which is not significant. If the $\mathrm{CO}$ ratio of $\mathrm{BB}$ origin to the anthropogenic origins increases to $30 \%$ in Central Mexico (Yokelson et al., 2007; Crouse et al., 2009) to account for the likely VOC emission underestimation, and assume a same $\mathrm{O}_{3}$ production rate, then the $\mathrm{BB}$ $\mathrm{O}_{3}$ contribution would become $4.5 \%$, still insignificant. It should be noted that a scaling of the BB VOC emissions may imply modifications to the emissions of other BB species, which could affect the model-measurements comparisons for species such as OA and EC. The underestimation of BB VOC emissions would probably have smaller effects on the $\mathrm{BB}_{3}$ impact in the MCMA due to the overwhelming dominance of anthropogenic VOC emissions. Further modeling investigations are needed to accurately evaluate the impact of the $\mathrm{BB}$ emissions on $\mathrm{O}_{3}$ production with accurate BB VOC emissions.

The BB exerts a dominant impact on POA concentration $(\sim 60 \%)$ on the local and regional scale (Fig. 10c-d), which is consistent with its dominance in the POA emissions. The BB exerts a slightly higher impact on SOA in the MCMA $(27 \%)$ than on the regional scale $(20 \%)$, similar to its contributions at $\mathrm{T} 0$ and $\mathrm{T} 1$. This indicates that the BB's impacts on SOA are quite spatially uniform. The impacts of $\mathrm{BB}$ on EC concentrations are about $20 \%$ on both the local and regional scales, but as mentioned above, this contribution may be overpredicted.

These simulated contributions of biomass burning to OA are much lower than their fractional contributions to the 

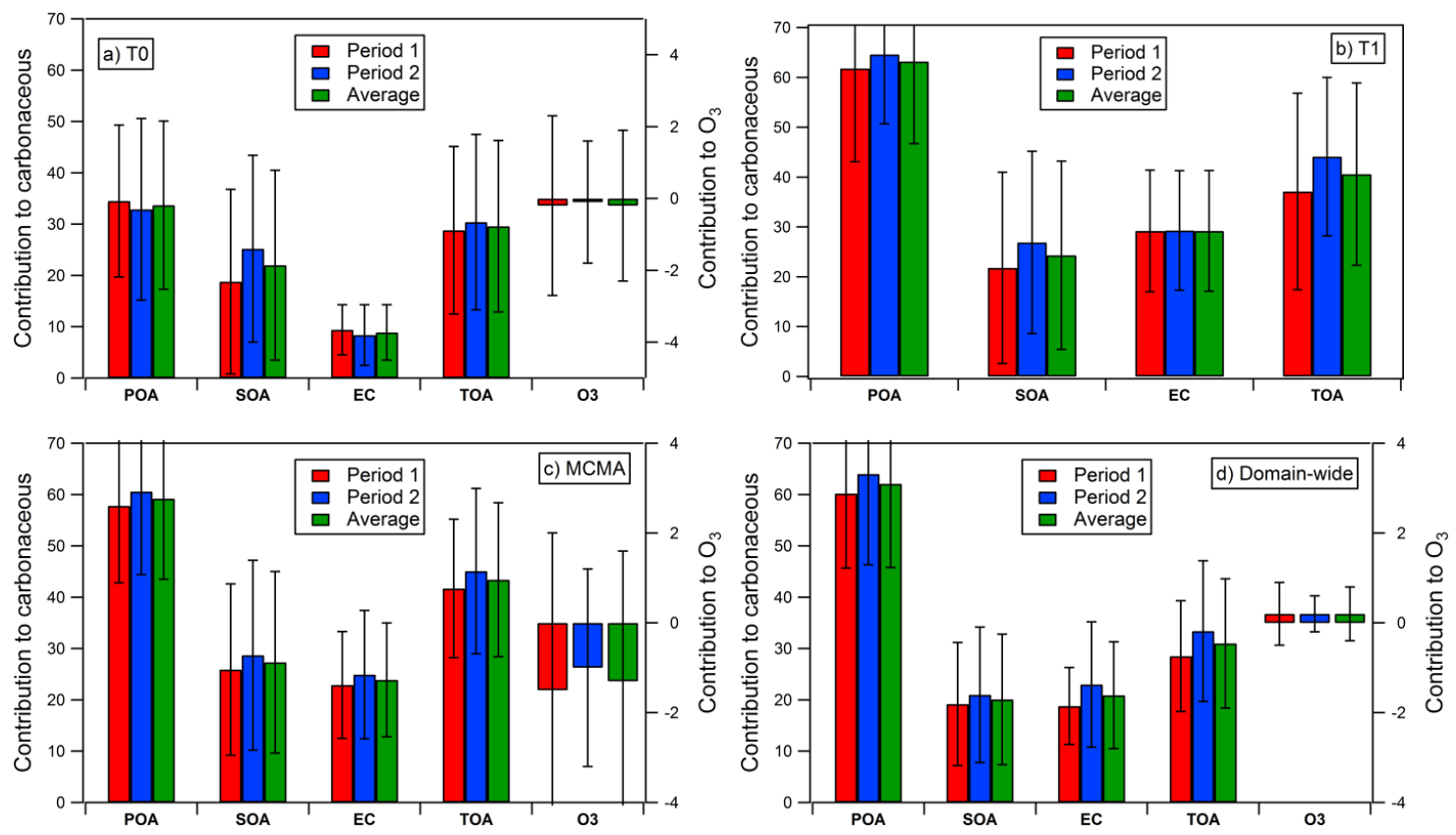

Fig. 10. Simulated $\mathrm{BB}$ impacts on $\mathrm{O}_{3}, \mathrm{OA}$ and $\mathrm{EC}$ at different locations. (a) $\mathrm{T} 0$, except the $\mathrm{O}_{3}$ concentrations are averaged over the RAMA stations, most of which are located in the MCMA urban area. (b) T1, (c) MCMA, and (d) domain-wide. The error bars in the figure represent the standard deviations.

emissions (see Sect. 2.2 and Table 2), mainly due to the difference of emission diurnal profiles in the anthropogenic and BB sources, where a large portion of anthropogenic components is emitted in the morning hours when the pollutants are trapped in the PBL, while the majority of BB components is released in the afternoon when the meteorology is more convective, and a longer chemical aging for the early morning anthropogenic emissions favor $\mathrm{O}_{3}$ and SOA formation. On the other hand, the simulated BB contributions to OA are higher than many of the ground observation-based estimates (where most lie below $20 \%$, see Table 1). This is probably because the simulated BB effects include the BBSOA contributions and the trash burning impacts while the observationbased estimates do not (or only include a very small portion), which we will discuss further later.

It is interesting to note, as shown in Fig. 10, that the BB impacts in the MCMA are similar to those at T1, the suburban site, but are different (particularly for POA) to those at $\mathrm{T} 0$, the urban site. This difference is probably mainly due to the high heterogeneity of the anthropogenic emissions in the MCMA, suggesting that measurement or simulation at one site (or a limited number of sites) may not represent the overall conditions of an urban area.

The simulated BB impacts are not significantly affected by the observation-derived BB extremities in the early morning of 11, 18 and 21 March, since the model did not capture the last two extreme events very well. The exclusion of the model data points in the time spans where the observed extreme events occurred in the early morning of 11,18 and 21
March would alter the simulated BB contributions to OA and EC by less than $2 \%$ in the MCMA.

\subsection{Partitioning of simulated BB impacts}

We have conducted case studies to estimate the contributions of open fires and trash burning to ground-level OA and EC through the Brute Force method. Figure 11 shows the partitioning of the contributions from sources of open fires and TB to OA and EC at T0 and T1. During the two high BB periods, at T0, the open fires contribute about $20 \%$ to POA, $17 \%$ to SOA, and $4 \%$ to EC, and TB contributes about $14 \%$ to POA, $5 \%$ to SOA, and $5 \%$ to EC, while other emission sources (anthropogenic and biogenic) contribute the rest. The contributions to TOA at T0 from the open fires and TB are $20 \%$ and $10 \%$, respectively. At T1, the contributions from the open fires and TB to SOA (18 and 6\%, respectively) are similar to those at T0, while their impacts on POA ( $31 \%$ and $33 \%$, respectively) enhance importantly, and their impacts on EC enhance even more, by a factor of 3 . The impacts of open fires and TB on TOA at T1 account for about 24 and $19 \%$, respectively.

We further estimate the BB partitioning on the local and regional scales (Fig. 11c-d). For POA, the contribution from open fires increases from $37 \%$ on the local scale to $54 \%$ on the regional scale; on the other hand, the TB contribution decreases from $23 \%$ in the MCMA to $8 \%$ on the regional scale. Similar to the case at T0 and T1, the impact of open fires on SOA is similar on the local and regional scales 

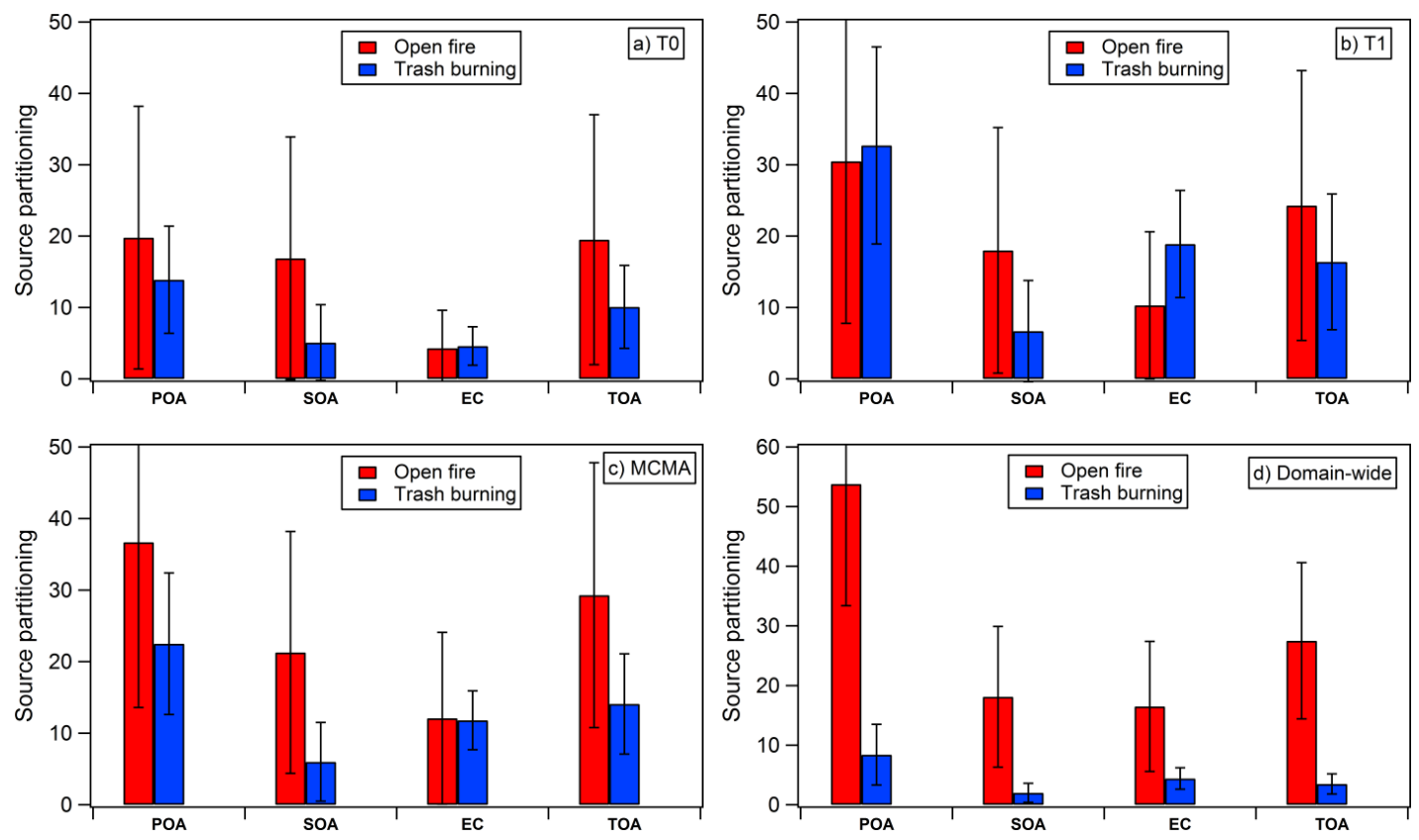

Fig. 11. Partitioning of the contributions of different emission sources to OA and EC concentrations (a) at T0, (b) at T1, (c) in MCMA, and (d) domain-wide. The error bars in the graph represent the standard deviations.

(18-21\%), but the TB has a smaller influence on the regional scale ( $2 \%$ vs. $6 \%$ ). The smaller regional impact of TB is due to the lack of TB emissions outside the MCMA as mentioned in Sect. 2.2.3., together with the high population density in the MCMA. On both the local and regional scales, the open fires have consistent influences on TOA $(\sim 30 \%)$, although open fires contribute relatively smaller within the MCMA. For EC, the contributions to the EC concentrations from the open fires and TB in the MCMA are similar, in contrast to the much higher EC emissions from the open fires. On the regional scale, open fires have relatively much higher impacts on EC compared to TB (16\% vs. $4 \%$ ). Nevertheless, other emission sources, such as fossil fuel consumption, dominate the EC concentrations.

There are several noticeable results in the estimates. First, the BB emissions make important impacts on the groundlevel concentrations of POA and TOA in the MCMA, accounting for about one-third of POA and TOA at T0 and $40-60 \%$ of POA and TOA at T1, while their influences on SOA are much smaller. Second, the influence of TB on TOA is smaller but surprisingly comparable to that of open fires in both the urban and suburban areas, and even higher contributions to EC, since the total emissions of POA and EC from the TB are much lower than the counterparts of the open fires during high BB periods. As discussed above, this is probably attributed to the difference of the emission timing coupled with the meteorological characteristics. Finally, the simulated impact of open fires on TOA at T0 $(\sim 20 \%)$ is consistent with many observation-based estimates. For example, the average $\mathrm{BB}$ contribution to $\mathrm{OA}$ is estimated to be about $11 \%$ by Stone et al. (2008), $18 \%$ by Querol et al. (2008), $19 \%$ by Aiken et al. (2010), and $20 \%$ by Gilardoni et al. (2009) (see Table 1). However, the simulated contribution is lower than the estimate of $27 \%$ by Aiken et al. (2010) during high fire periods, which is mainly due to the fact that the model failed to capture the extremely high BBPOA concentrations observed in the early morning on 18 and 21 March.

The tracer- or PMF- based observation estimations of BB impacts usually do not include the TB influence. Furthermore, most observation-based estimations do not include SOA formed from the biomass burning (BBSOA). If BBSOA is included, according to our simulations, the contribution of open fires to OA would be additional $8 \%$ and $11 \%$ at T0 and T1, respectively, while BBSOA from TB contributes about $5 \%$ to TOA in the suburban area. This is contrast to the findings of Aiken et al. (2010) who reported very minor contributions of BB to SOA. Their estimates on the BBSOA effects were based on the change of SOA during high and low fire periods, and thus may be subject to the probable differences in meteorological conditions during different periods.

\section{Broader BB impacts}

\subsection{Extrapolation of BB's monthly and annual impacts}

In the previous section, we have calculated the BB impacts during the two high-fire periods. A more general question of interest is what are the BB's overall impacts monthly or even 
annually. In this section, we will estimate the longer-term impacts based on the simulation results of the two events and the $\mathrm{BB}$ emissions for a longer time period, assuming that the $\mathrm{BB}$ impacts can be linearly scaled according to the BB emissions.

On both local and regional scale, the BB emissions (open fires $+\mathrm{TB}$ ) accounted for $75 \%$ to the total POA emissions and $35 \%$ to the total particulate EC emissions during the simulation period, while the BB emissions accounted for about $65 \%$ and $25 \%$, respectively, to the total POA and EC emissions in March 2006. During the simulation period, BB contributes $60 \%$ to the POA concentrations on the local and regional scales, and about $20 \%$ to the EC concentrations. Assuming the BB impact (on POA and EC) is proportional to its emissions, we can estimate that BB contributes about $50 \%$ and $15 \%$ to POA and EC, respectively, on both local and regional scales in March 2006. Similarly, we estimate that the BB contributes $20 \%$ to SOA in March 2006. On the annual basis, according to the MODIS hotspot data for the year 2006 in Mexico (nationally), the hotspot number during March accounted for about $9 \%$ of the total. Assuming a linear relation between the $\mathrm{BB}$ emissions and the fire counts, we expect that the contribution of BB to POA, SOA and EC on the annual basis would be about $90 \%(\approx 1 / 12 / 0.09 \cdot 100)$ of those in March, i.e., 45, 18 and $14 \%$, respectively, both on the local and regional scales.

\subsection{Estimation of the impacts of biofuel use}

Due to the unavailability of the emission inventory for the domestic and industrial biofuel use, we have not directly calculated the impacts of the biofuel use on OA. However, it is possible to estimate its influence in a first-order approximation by combining the simulation results above and the emission amounts from the biofuel use with some assumptions. Christian et al. (2010) and Yokelson et al. (2011) estimated that on the annual basis, the emissions from the domestic and industrial biofuel use account for about $39 \%$ of the total BB emissions for $\mathrm{PM}_{2.5}$ (open fires accounting for $52 \%$ ) in Mexico. Assuming that the biofuel emissions and transformations behave similarly as the open fires and TB do in affecting the air quality and photochemistry, we estimate, on the annual basis, that the biofuel use emissions would contribute about 25,12 , and $10 \%$, respectively, to the total concentrations of POA, SOA, and EC in both MCMA and its surrounding region, while the open fires and TB emissions combined would contribute about 35,18 , and $15 \%$, respectively (note here the total concentrations include the contribution from the biofuel use, i.e. the denominator changes). The annual contributions to POA, SOA and EC loadings from all the BB sources (open fires, TB and biofuel use) would then be $60 \%$, $30 \%$, and $25 \%$, respectively. We are aware that there may be large uncertainties in this estimation, which originated from the emission estimation, temporal variations of the emissions and the linear-response scaling approach, however, this is the best assessment we are able to obtain with the information available.

\subsection{Implications of the BB emissions on air quality and prescribed fire control}

Open fire emissions are generally estimated from the total biomass consumption and the temporal-spatial distribution is typically retrieved from satellite detection of hotspots and/or burned areas) in conjunction with field-measured emission factors. Due to the inherent limitations of the satellite detection technique (such as low overpass frequency, difficulty in detecting fires of small size and short duration, and clouds), the retrieved biomass consumption estimate and fire distribution are highly uncertain (Wiedinmyer et al., 2011). The BB field-measured emission factors also vary considerably from fire to fire due to factors such as burning type (smoldering vs. flaming) and meteorological conditions (Yokelson et al., 2007, 2011). The TB emission estimates contains even higher uncertainties (Christian et al., 2010), due to the difficulty in accurately estimating the amount of garbage generated, amount of garbage burned, and the composition of garbage, etc. Nevertheless, considering the very low $\mathrm{VOC} / \mathrm{CO}$ ratios in the $\mathrm{BB}$ emissions and a low $\mathrm{CO}$ ratio of the $\mathrm{BB}$ sources to the anthropogenic sources, the BB emission estimates are likely underestimated in Mexico City (Yokelson et al., 2011; Christian et al., 2010). Therefore the BB emissions presented at Table 1 and the BB impacts shown above are not the upper limits of the BB effects in Mexico City. BB is a major emitter of POA in the MCMA and at regional scales, surpassing the anthropogenic sources. On the national scale, Yokelson et al. (2011) estimate that BB emissions are large enough to be of major importance for particulates and many gaseous species in Mexico.

The BB emissions and their impacts on air quality on local and regional scales in Mexico have important implications in urban and regional air quality studies. First, any PM modeling studies should include the BB emissions, which are generally severely underestimated in the official emission inventories. On the other hand, the impact of $\mathrm{BB}$ on $\mathrm{O}_{3}$ concentrations is mostly likely negligible in the MCMA and the surrounding region despite probable underestimates of the $\mathrm{BB}$ emissions, due to their moderate contributions to the $\mathrm{O}_{3}$ precursors (VOCs and $\mathrm{NO}_{\mathrm{x}}$ ) and the offset effects of BB-originating aerosols on $\mathrm{O}_{3}$ formation. This is in contrast to the BB's important role $(\sim 38 \%)$ in tropospheric $\mathrm{O}_{3}$ at the global scale (Andreae, 1991; Levine et al., 1995).

As pointed out previously, the BB impact is sensitive to the temporal profile of the BB emissions, with higher influences for biomass burned at nighttime (from evening to early morning next day) with significantly reduced influences for daytime fires. This verifies the effectiveness in the management of planning or prescribing fires during the daytime (best in the early afternoon) to reduce fuels and wildfire hazards 
before the fire season start (Hardy et al., 2001). The same management also holds for garbage burning.

The BB impact on elemental carbon, as illustrated in this study, is moderate in the MCMA (9\%), but becomes more important at the regional scale $(\sim 30 \%)$. Considering the higher hygroscopicity and relatively short lifetime of the BB - produced EC (BBEC) compared with that of the fossil fuelorigin EC (Petters et al., 2009), the local and regional climate warming effect induced by BBEC is probably not significant in Mexico City.

\subsection{Comparison to other model studies of TB}

This model exercise uses similar open fire and TB emissions as another recent model-based study focused on TB impacts (Hodzic et al., 2012). As a result, the contributions of TB to MCMA OA are similar in both studies in general, except a slightly higher TB impact from our study. However, the general agreement does not indicate a high level of certainty in the TB or even BB impacts. Much of the uncertainty stems from the approximate factor of two uncertainties in anthropogenic POA and VOC, BB POA and VOC, and even higher uncertainty in TB POA and VOC. SOA production is most studied from the anthropogenic source and has been found to be highly variable for reasons that are poorly understood. SOA from the other sources is less studied (BB) or completely unmeasured/unstudied (TB). The measurements of OOA, HOA, BBOA, etc., are based on simplifying algorithms applied to complex mass spectra. The derived quantities are useful, but have non-negligible error that may be incompletely characterized in some complex environments. The actual controlled quantity from an air quality perspective is $\mathrm{PM}_{2.5}$. The MCMA has prodigious emissions of $\mathrm{NO}_{\mathrm{x}}$ and $\mathrm{SO}_{2}$ which will convert to $\mathrm{PM}_{2.5}$ in ways that depend on meteorology and a changing mix of co-emitted species. The arid climate of the MCMA and the nearby agriculture lead to a large dust component to the aerosol, which present another challenge. Antimony (Sb) has been used to estimate TB impacts as upper limits (Christian et al., 2010) or for lower central estimates (Hodzic et al., 2012), but Sb is also produced by vehicle brake pads and other sources such as metal processing (Christian et al., 2010). The brake pad source, unlike $\mathrm{TB}$, also produces large amounts of $\mathrm{Ba}$, but in varying ratios to $\mathrm{Sb}$ in different studies (Sternbeck et al., 2002; Schauer et al., 2006). Thus as proposed by Christian et al. (2010) a multi-species analysis based on a suite of metals with locally measured source profiles for TB, vehicles, and any smelters or other Sb sources would likely offer the best way forward to quantify the impacts. In addition, most of the intensive measurement campaigns in the MCMA have been made in the springtime and it would be worthwhile to implement largescale efforts at other periods of the year.

\section{Conclusions}

Biomass burning (open fires and trash burning) contributes substantially to the OA emissions in the MCMA and its surrounding areas, while their contributions to the aerosol precursors are relatively minor compared to the anthropogenic sources. In the present study, the emissions of aerosols and aerosol precursors from the open fires were calculated based on emission factors and emission ratios measured during the MILAGRO campaign together with the MODIS fire detection data. The trash burning emissions were estimated based on the garbage fire emissions factors measured during MILAGRO combined with literature values and a spatial distribution of population and socioeconomic classifications in Mexico City. We have employed WRF-CHEM during two high fire periods to assess the impacts of open fires and garbage burning on the air quality in and around the MCMA, with emphases on $\mathrm{O}_{3}$, organic aerosols and elemental carbon. The model has captured reasonably well the measurementderived magnitude and temporal variation of the biomass burning OA in and near Mexico City, with no systematic biases found at the T0 urban site, while a higher bias exists in the $\mathrm{T} 1$ suburban site.

From this study while we did not detect significant effects of open fires and trash burning on ground-level $\mathrm{O}_{3}$ concentrations in the MCMA and surrounding region, they make important contributions to the ground-level OA and EC locally and regionally, contributing about $34 \%$ to POA, $22 \%$ to SOA, and $9 \%$ to and $\mathrm{EC}$ at T0, and contributing even higher at $\mathrm{T} 1(63 \%$ to POA, $24 \%$ to SOA, and $29 \%$ to EC) during the high fire events. Of the $\sim 22 \%$ enhancement in SOA concentrations (equivalent to a $\sim 15 \%$ increase in TOA) simulated in the MCMA, about two third is attributed to open fires and one-third is attributed to trash burning. It is noted that the $\mathrm{BB}$ impacts on $\mathrm{OA}$ are highly variable temporally and spatially, consistent with the measurements. Trash burning makes slightly smaller contributions to OA than open fires in the MCMA, while exerting higher influences to EC compared to the latter, although the TB emissions are much lower than those of open fires during high fire periods. The simulated impacts of open fires on OA at $T 0(\sim 20 \%)$ are consistent with many observation-based estimates during the MILAGRO campaign. SOA formation due to the BB emission enhances the OA concentration by about $10 \%$ in and around the MCMA.

Extrapolating the simulations to the entire month of March 2006 based on the emissions of open fires and trash burning during this month, we estimate that the open fires and trash burning contribute about 50,20 , and $15 \%$, respectively, to the ambient concentrations of POA, SOA and EC in and around the MCMA. Taking the extrapolation one step further and taking the emissions from the biofuel use into consideration, we estimate that, on the first- order approximation, biomass burning contributes about 60,30 and $25 \%$, respectively, to the loading of POA, SOA and EC in and round the 
MCMA, of which open fires and trash burning account for 35,18 , and $15 \%$ to the total loading of POA, SOA and EC.

It should be noted that although the simulated biomass burning OA are in good agreement with observations, the model-based estimates of the BB impacts may contain significant uncertainties due to the uncertainties in the BB emission estimates (magnitude, temporal and spatial distribution, etc.), extrapolations and the nature of spot comparison, which is subject to the bias of transport and local emission influences. The impact of the emissions from the biofuel use, a major BB source in Mexico, is implicitly extrapolated instead of explicitly simulated. In addition, TB emissions outside the MCMA are not included in this study, which implies that the TB impacts would otherwise be higher than we estimate on the regional scale. More modeling studies are needed to accurately assess the BB impacts through better characterizing $\mathrm{BB}$ emissions and employing airborne measurements with wide spatial and temporal coverages.

Acknowledgements. We are grateful to R. Yokelson for his valuable discussions and comments and to C. Wiedinmyer for providing the emission inventories of the open fires and trash burning used in this study and for her helpful comments. We also acknowledge the anonymous reviewers for their constructive comments which helped to improve the quality of this article. This work was supported by National Science Foundation (Award \# 1135141) and the Molina Center for Energy and the Environment. G. Li acknowledges support from MIT Molina Fellowship. We would like to thank the computing resources provided by NCAR's Computational and Information Systems Laboratory, sponsored by NSF.

Edited by: M. Gauss

\section{References}

Aiken, A. C., Salcedo, D., Cubison, M. J., Huffman, J. A., DeCarlo, P. F., Ulbrich, I. M., Docherty, K. S., Sueper, D., Kimmel, J. R., Worsnop, D. R., Trimborn, A., Northway, M., Stone, E. A., Schauer, J. J., Volkamer, R. M., Fortner, E., de Foy, B., Wang, J., Laskin, A., Shutthanandan, V., Zheng, J., Zhang, R., Gaffney, J., Marley, N. A., Paredes-Miranda, G., Arnott, W. P., Molina, L. T., Sosa, G., and Jimenez, J. L.: Mexico City aerosol analysis during MILAGRO using high resolution aerosol mass spectrometry at the urban supersite (T0) - Part 1: Fine particle composition and organic source apportionment, Atmos. Chem. Phys., 9, 6633-6653, doi:10.5194/acp-10-5315-2010, 2009.

Aiken, A. C., de Foy, B., Wiedinmyer, C., DeCarlo, P. F., Ulbrich, I. M., Wehrli, M. N., Szidat, S., Prevot, A. S. H., Noda, J., Wacker, L., Volkamer, R., Fortner, E., Wang, J., Laskin, A., Shutthanandan, V., Zheng, J., Zhang, R., Paredes-Miranda, G., Arnott, W. P., Molina, L. T., Sosa, G., Querol, X., and Jimenez, J. L.: Mexico city aerosol analysis during MILAGRO using high resolution aerosol mass spectrometry at the urban supersite (T0) Part 2: Analysis of the biomass burning contribution and the non-fossil carbon fraction, Atmos. Chem. Phys., 10, 5315-5341, doi:10.5194/acp-10-5315-2010, 2010.
Akagi, S. K., Yokelson, R. J., Wiedinmyer, C., Alvarado, M. J., Reid, J. S., Karl, T., Crounse, J. D., and Wennberg, P. O.: Emission factors for open and domestic biomass burning for use in atmospheric models, Atmos. Chem. Phys., 11, 4039-4072, doi:10.5194/acp-11-4039-2011, 2011.

Andreae, M. O.: Global Biomass Burning: Atmospheric, Climatic, and Biospheric Implications, edited by: Levine, J. S., The MIT Press, Cambridge, MA, USA, 1991.

Andreae, M. O. and Merlet, P.: Emission of trace gases and aerosols from biomass burning, Global Biochem. Cy., 15, 955-966, 2001.

Bahreini, R., Ervens, B., Middlebrook, A. M., Warneke, C., de Gouw, J. A., DeCarlo, P. F., Jimenez, J. L., Brock, C. A., Neuman, J. A., Ryerson, T. B., Stark, H., Atlas, E., Brioude, J., Fried, A., Holloway, J. S., Peischl, J., Richter, D., Walega, J., Weibring, P., Wollny, A. G., and Fehsenfeld, F. C.: Organic aerosol formation in urban and industrial plumes near Houston and Dallas, Texas, J. Geophys. Res., 114, D00F16, doi:10.1029/2008JD011493, 2009.

Binkowski, F. S. and Roselle S. J.: Models-3 Community Multiscale Air Quality (CMAQ) model aerosol component: 1. Model description, J. Geophys. Res., 108, 4183, doi:10.1029/2001JD001409, 2003.

Bond, T. C., Streets, D. G., Yarber, K. F., Nelson, S. M., Woo, J.-H., and Klimont, Z.: A technology-based global inventory of black and organic carbon emissions from combustion, J. Geophys. Res., 109, D14203, doi:10.1029/2003JD003697, 2004.

Bravo, A., Sosa, E., Sanchez, A., Jaimes, P., and Saavedra, R.: Impact of wildfires on the air quality of Mexico City, 1992-1999, Environ. Pollut., 117, 243-253, 2002.

Chen, F. and Dudhia, J.: Coupling an advanced land-surface/hydrology model with the Penn State/NCARMM5modelingsystem. Part I: Model description and implementation, Mon. Weather Rev., 129, 569-585, 2001.

Christian, T. J., Yokelson, R. J., Cárdenas, B., Molina, L. T., Engling, G., and Hsu, S.-C.: Trace gas and particle emissions from domestic and industrial biofuel use and garbage burning in central Mexico, Atmos. Chem. Phys., 10, 565-584, doi:10.5194/acp10-565-2010, 2010.

Crounse, J. D., DeCarlo, P. F., Blake, D. R., Emmons, L. K., Campos, T. L., Apel, E. C., Clarke, A. D., Weinheimer, A. J., McCabe, D. C., Yokelson, R. J., Jimenez, J. L., and Wennberg, P. O.: Biomass burning and urban air pollution over the Central Mexican Plateau, Atmos. Chem. Phys., 9, 4929-4944, doi:10.5194/acp-9-4929-2009, 2009.

Davies, D. K., Ilavajhala, S., Wong, M. M., and Justice, C. O.: Fire Information for Resource Management System: Archiving and Distributing MODIS Active Fire Data, IEEE T. Geosci. Remote Sens., 47, 72-79, 2009.

DeCarlo, P. F., Dunlea, E. J., Kimmel, J. R., Aiken, A. C., Sueper, D., Crounse, J., Wennberg, P. O., Emmons, L., Shinozuka, Y., Clarke, A., Zhou, J., Tomlinson, J., Collins, D. R., Knapp, D., Weinheimer, A. J., Montzka, D. D., Campos, T., and Jimenez, J. L.: Fast airborne aerosol size and chemistry measurements above Mexico City and Central Mexico during the MILAGRO campaign, Atmos. Chem. Phys., 8, 4027-4048, doi:10.5194/acp-84027-2008, 2008.

DeCarlo, P. F., Ulbrich, I. M., Crounse, J., de Foy, B., Dunlea, E. J., Aiken, A. C., Knapp, D., Weinheimer, A. J., Campos, 
T., Wennberg, P. O., and Jimenez, J. L.: Investigation of the sources and processing of organic aerosol over the Central Mexican Plateau from aircraft measurements during MILAGRO, Atmos. Chem. Phys., 10, 5257-5280, doi:10.5194/acp-10-52572010, 2010.

de Foy, B., Fast, J. D., Paech, S. J., Phillips, D., Walters, J. T., Coulter, R. L., Martin, T. J., Pekour, M. S., Shaw, W. J., Kastendeuch, P. P., Marley, N. A., Retama, A., and Molina, L. T.: Basinscale wind transport during the MILAGRO field campaign and comparison to climatology using cluster analysis, Atmos. Chem. Phys., 8, 1209-1224, doi:10.5194/acp-8-1209-2008, 2008.

de Gouw, J. A.,Welsh-Bon, D.,Warneke, C., Kuster,W. C., Alexander, L., Baker, A. K., Beyersdorf, A. J., Blake, D. R., Canagaratna, M., Celada, A. T., Huey, L. G., Junkermann,W., Onasch, T. B., Salcido, A., Sjostedt, S. J., Sullivan, A. P., Tanner, D. J., Vargas, O., Weber, R. J., Worsnop, D. R., Yu, X. Y., and Zaveri, R.: Emission and chemistry of organic carbon in the gas and aerosol phase at a sub-urban site near Mexico City in March 2006 during the MILAGRO study, Atmos. Chem. Phys., 9, 34253442, doi:10.5194/acp-9-3425-2009, 2009.

Dudhia, J.: Numerical study of convection observed during the winter monsoon experiment using a mesoscale two-dimensional model, J. Atmos. Sci., 46, 3077-3107, 1989.

Dzepina, K., Volkamer, R. M., Madronich, S., Tulet, P., Ulbrich, I. M., Zhang, Q., Cappa, C. D., Ziemann, P. J., and Jimenez, J. L.: Evaluation of recently-proposed secondary organic aerosol models for a case study in Mexico City, Atmos. Chem. Phys., 9, 5681-5709, doi:10.5194/acp-9-5681-2009, 2009.

Emmons, L. K., Apel, E. C., Lamarque, J.-F., Hess, P. G., Avery, M., Blake, D., Brune, W., Campos, T., Crawford, J., DeCarlo, P. F., Hall, S., Heikes, B., Holloway, J., Jimenez, J. L., Knapp, D. J., Kok, G., Mena-Carrasco, M., Olson, J., O’Sullivan, D., Sachse, G., Walega, J., Weibring, P., Weinheimer, A., and Wiedinmyer, C.: Impact of Mexico City emissions on regional air quality from MOZART-4 simulations, Atmos. Chem. Phys., 10, 6195-6212, doi:10.5194/acp-10-6195-2010, 2010.

Fast, J., Aiken, A. C., Allan, J., Alexander, L., Campos, T., Canagaratna, M. R., Chapman, E., DeCarlo, P. F., de Foy, B., Gaffney, J., de Gouw, J., Doran, J. C., Emmons, L., Hodzic, A., Herndon, S. C., Huey, G., Jayne, J. T., Jimenez, J. L., Kleinman, L., Kuster, W., Marley, N., Russell, L., Ochoa, C., Onasch, T. B., Pekour, M., Song, C., Ulbrich, I. M., Warneke, C., WelshBon, D.,Wiedinmyer, C.,Worsnop, D. R., Yu, X.-Y., and Zaveri, R.: Evaluating simulated primary anthropogenic and biomass burning organic aerosols during MILAGRO: implications for assessing treatments of secondary organic aerosols, Atmos. Chem. Phys., 9, 6191-6215, doi:10.5194/acp-9-6191-2009, 2009.

Gilardoni, S., Liu, S., Takahama, S., Russell, L. M., Allan, J. D., Steinbrecher, R., Jimenez, J. L., De Carlo, P. F., Dunlea, E. J., and Baumgardner, D.: Characterization of organic ambient aerosol during MIRAGE 2006 on three platforms, Atmos. Chem. Phys., 9, 5417-5432, doi:10.5194/acp-9-5417-2009, 2009.

Grell, G. A., Peckham, S. E., Schmitz, R., McKeen, S. A., Wilczak, J., and Eder, B.: Fully coupled "online" chemistry within the WRF model, Atmos. Environ., 39, 6957-6975, 2005.

Grieshop, A. P., Logue, J. M., Donahue, N. M., and Robinson, A. L.: Laboratory investigation of photochemical oxidation of organic aerosol from wood fires 1: measurement and simulation of organic aerosol evolution, Atmos. Chem. Phys., 9, 1263-1277, doi:10.5194/acp-9-1263-2009, 2009.

Hardy, C.,C., Ottmar, R. D., Peterson, J., L., Core, J. E., and Seamon, P.: Smoke management guide for prescribed and wildland fire; 2001 ed., PMS 420-2, National Wildfire Coordinating group, Boise, 226 pp., 2001.

Hodzic, A., Jimenez, J. L., Madronich, S., Aiken, A. C., Bessagnet, B., Curci, G., Fast, J., Lamarque, J.-F., Onasch, T. B., Roux, G., Schauer, J. J., Stone, E. A., and Ulbrich, I. M.: Modeling organic aerosols during MILAGRO: importance of biogenic secondary organic aerosols, Atmos. Chem. Phys., 9, 6949-6981, doi:10.5194/acp-9-6949-2009, 2009.

Hodzic, A., Jimenez, J. L., Madronich, S., Canagaratna, M. R., DeCarlo, P. F., Kleinman, L., and Fast, J.: Modeling organic aerosols in a megacity: potential contribution of semi-volatile and intermediate volatility primary organic compounds to secondary organic aerosol formation, Atmos. Chem. Phys., 10, 5491-5514, doi:10.5194/acp-10-5491-2010, 2010a.

Hodzic, A., Wiedinmyer, C., Salcedo, D., and Jimenez, J.L.: Impact of Trash Burning on Air Quality in Mexico City, Environ. Sci. Technol., 46, 4950-4957, 2012.

Horowitz, L. W., Walter, S., Mauzerall, D. L., Emmons, L. K., Rasch, P. J., Granier, C., Tie, X., Lamarque, J.-F., Schultz, M. G., Tyndall, G. S., Orlando, J. J., and Brasseur, G. P.: A global simulation of tropospheric ozone and related tracers: Description and evaluation of MOZART, version 2, J. Geophys. Res., 108, 4784, doi:10.1029/2002JD002853, 2003.

Jaffe, D. A. and Widger, N. L.: Ozone production from wildfires: A critical review, Atmos. Environ., 51, 1-10, 2012.

Kain, J. S.: The Kain-Fritsch convection parameterization: an update. J. Appl. Meteorol., 43, 170-181, 2004.

Kleinman, L. I., Springston, S. R., Daum, P. H., Lee, Y.-N., Nunnermacker, L. J., Senum, G. I., Wang, J., Weinstein-Lloyd, J., Alexander, M. L., Hubbe, J., Ortega, J., Canagaratna, M. R., and Jayne, J.: The time evolution of aerosol composition over the Mexico City plateau, Atmos. Chem. Phys., 8, 1559-1575, doi:10.5194/acp-8-1559-2008, 2008.

Lane, T. E., Donahue, N. M., and Pandis, S. N.: Simulating secondary organic aerosol formation using the volatility basis-set approach in a chemical transport model, Atmos. Environ., 42, 7439-7451, 2008a.

Lane, T. E., Donahue, N. M., and Pandis, S. N.: Effect of NOx on secondary organic aerosol concentrations, Environ. Sci. Technol., 42, 6022-6027, 2008b.

Lemieux, P. M., Lutes, C. C., and Santoianni, D. A.: Emissions of organic air toxics from open burning: a comprehensive review, Prog. Energ. Combust., 20, 1-32, 2004.

Levine, J. S., Cofer, W. R., Cahoon, D. R., and Winstead, E. L.: Biomass Burning: A Driver for Global Change, Environ. Sci. Tech., 29, 120A-125A, 1995.

Li, G., Lei, W., Zavala, M., Volkamer, R., Dusanter, S., Stevens, P., and Molina, L. T.: Impacts of HONO sources on the photochemistry in Mexico City during the MCMA-2006/MILAGO Campaign, Atmos. Chem. Phys., 10, 6551-6567, doi:10.5194/acp-106551-2010, 2010.

Li, G., Zavala, M., Lei, W., Tsimpidi, A. P., Karydis, V. A., Pandis, S. N., Canagaratna, M. R., and Molina, L. T.: Simulations of organic aerosol concentrations in Mexico City using the WRFCHEM model during the MCMA-2006/MILAGRO campaign, Atmos. Chem. Phys., 11, 3789-3809, doi:10.5194/acp-11-3789- 
2011, 2011.

Li, G., Lei, W., Bei, N., and Molina, L. T.: Contribution of garbage burning to chloride and $\mathrm{PM}_{2.5}$ in Mexico City, Atmos. Chem. Phys. 12, 8751-8761, doi:10.5194/acp-12-8751-2012, 2012.

Lin Y.-L., Farley, R. D., and Orville, H. D.: Bulk parameterization of the snow field in a cloud model, J. Appl. Meteorol., 22, 10651092, 1983.

Liu, S., Takahama, S., Russell, L. M., Gilardoni, S., and Baumgardner, D.: Oxygenated organic functional groups and their sources in single and submicron organic particles in MILAGRO 2006 campaign, Atmos. Chem. Phys., 9, 6849-6863, doi:10.5194/acp9-6849-2009, 2009.

Marley, N. A., Gaffney, J. S., Tackett, M., Sturchio, N. C., Heraty, L., Martinez, N., Hardy, K. D., Marchany-Rivera, A., Guilderson, T., MacMillan, A., and Steelman, K.: The impact of biogenic carbon sources on aerosol absorption in Mexico City, Atmos. Chem. Phys., 9, 1537-1549, 2009a,

http://www.atmos-chem-phys.net/9/1537/2009/.

Marley, N. A., Gaffney, J. S., Castro, T., Salcido, A., and Frederick, J.: Measurements of aerosol absorption and scattering in the Mexico City Metropolitan Area during the MILAGRO field campaign: a comparison of results from the T0 and T1 sites, Atmos. Chem. Phys., 9, 189-206, doi:10.5194/acp-9-189-2009, 2009 b.

Mlawer, E. J., Taubman, S. J., Brown, P. D., Iacono, M. J., and Clough, S. A.: Radiative transfer for inhomogeneous atmosphere: RRTM, a validated correlated-k model for the long-wave, J. Geophys. Res., 102, 16663-16682, 1997.

Moffet, R. C., de Foy, B., Molina, L. T., Molina, M. J., and Prather, K. A.: Measurement of ambient aerosols in northern Mexico City by single particle mass spectrometry, Atmos. Chem. Phys., 8, 4499-4516, doi:10.5194/acp-8-4499-2008, 2008.

Mohr, C., DeCarlo, P. F., Heringa, M. F., Chirico, R., Slowik, J. G., Richter, R., Reche, C., Alastuey, A., Querol, X., Seco, R., Peñuelas, J., Jiménez, J. L., Crippa, M., Zimmermann, R., Baltensperger, U., and Prévôt, A. S. H.: Identification and quantification of organic aerosol from cooking and other sources in Barcelona using aerosol mass spectrometer data, Atmos. Chem. Phys., 12, 1649-1665, doi:10.5194/acp-12-1649-2012, 2012.

Molina, L. T., Kolb, C. E., de Foy, B., Lamb, B. K., Brune, W. H., Jimenez, J. L., Ramos-Villegas, R., Sarmiento, J., ParamoFigueroa, V. H., Cardenas, B., Gutierrez-Avedoy, V., and Molina, M. J.: Air quality in North America's most populous city overview of the MCMA-2003 campaign, Atmos. Chem. Phys., 7, 2447-2473, doi:10.5194/acp-7-2447-2007, 2007.

Molina, L. T., Madronich, S., Gaffney, J. S., Apel, E., de Foy, B., Fast, J., Ferrare, R., Herndon, S., Jimenez, J. L., Lamb, B., Osornio-Vargas, A. R., Russell, P., Schauer, J. J., Stevens, P. S., Volkamer, R., and Zavala, M.: An overview of the MILAGRO 2006 Campaign: Mexico City emissions and their transport and transformation, Atmos. Chem. Phys., 10, 8697-8760, doi:10.5194/acp-10-8697-2010, 2010.

Ng, N. L., Kroll, J. H., Chan, A. W. H., Chhabra, P. S., Flagan, R. C., and Seinfeld, J. H.: Secondary organic aerosol formation from m-xylene, toluene, and benzene, Atmos. Chem. Phys., 7, 3909-3922, doi:10.5194/acp-7-3909-2007, 2007.

Ojeda-Beñítez, S., Armijo-de Vega, C., and Ysabel MarquezMontenegro, M.: Household solid waste characterization by family socioeconomic profile as unit of analysis, Resour. Conserv. Recycl., 52, 992-999, 2008.
Petters, M. D., Carrico, C. M., Kreidenweis, S. M., Prenni, A. J., DeMott, P. J., Collett, J. L., and Moosmüller, H.: Cloud condensation nucleation activity of biomass burning aerosol, J. Geophys. Res., 114, D22205, doi:10.1029/2009jd012353, 2009.

Querol, X., Pey, J., Minguillón, M. C., Pérez, N., Alastuey, A., Viana, M., Moreno, T., Bernabé, R. M., Blanco, S., Cárdenas, B., Vega, E., Sosa, G., Escalona, S., Ruiz, H., and Artíñano, B.: PM speciation and sources in Mexico during the MILAGRO-2006 Campaign, Atmos. Chem. Phys., 8, 111-128, doi:10.5194/acp8-111-2008, 2008.

Robinson, A. L., Donahue, N. M., Shrivastava, M. K.,Weitkamp, E. A., Sage, A. M., Grieshop, A. P., Lane, T. E., Pandis, S. N., and Pierce, J. R.: Rethinking organic aerosols: semivolatile emissions and photochemical aging, Science, 315, 1259-1262, 2007.

Salcedo, D., Onasch, T. B., Dzepina, K., Canagaratna, M. R., Zhang, Q., Huffman, J. A., DeCarlo, P. F., Jayne, J. T., Mortimer, P., Worsnop, D. R., Kolb, C. E., Johnson, K. S., Zuberi, B., Marr, L. C., Volkamer, R., Molina, L. T., Molina, M. J., Cardenas, B., Bernabé, R. M., Márquez, C., Gaffney, J. S., Marley, N. A., Laskin, A., Shutthanandan, V., Xie, Y., Brune, W., Lesher, R., Shirley, T., and Jimenez, J. L.: Characterization of ambient aerosols in Mexico City during the MCMA-2003 campaign with Aerosol Mass Spectrometry: results from the CENICA Supersite, Atmos. Chem. Phys., 6, 925-946, doi:10.5194/acp-6-925-2006, 2006.

Schauer, J. J., Lough, G. C., Shafer, M. M., Christensen, W. F., Arndt, M. F., DeMinter, J. T., and Park, J.-S.: Characterization of Metals Emitted from Motor Vehicles, Health Effects Institute, Boston, MA, 2006. Song, J., Lei, W., Bei, N., Zavala, M., de Foy, B., Volkamer, R., Cardenas, B., Zheng, J., Zhang, R., and Molina, L. T.: Ozone response to emission changes: a modeling study during the MCMA-2006/MILAGRO Campaign, Atmos. Chem. Phys., 10, 3827-3846, doi:10.5194/acp-10-3827-2010, 2010.

Sternbeck, J., Sjödin, A., and Andréasson, K.: Metal emissions from road traffic and the influence of resuspension - results from two tunnel studies, Atmos. Environ., 36, 4735-4744, 2002.

Stone, E. A., Snyder, D. C., Sheesley, R. J., Sullivan, A. P., Weber, R. J., and Schauer, J. J.: Source apportionment of fine organic aerosol in Mexico City during the MILAGRO experiment 2006, Atmos. Chem. Phys., 8, 1249-1259, doi:10.5194/acp-81249-2008, 2008.

Sukoriansky, S., Galperin, B., and Perov, V.: Application of a new spectral theory of stably stratified turbulence to the atmospheric boundary layer over sea ice, Bound.-Layer Meteorol., 117, 231 257, 2005.

Tie, X., Madronich, S., Li, G., Ying, Z., Zhang, R., Garcia, A. R., Taylor, L., and Liu, Y.: Characterizations of chemical oxidants in Mexico City: A regional chemical dynamical model (WRFChem) study, Atmos. Environ., 41, 1989-2008, 2007.

Tsimpidi, A. P., Karydis, V. A., Zavala, M., Lei, W., Molina, L., Ulbrich, I. M., Jimenez, J. L., and Pandis, S. N.: Evaluation of the volatility basis-set approach for the simulation of organic aerosol formation in the Mexico City metropolitan area, Atmos. Chem. Phys., 10, 525-546, doi:10.5194/acp-10-525-2010, 2010.

Ulbrich, I. M., Canagaratna, M. R., Zhang, Q., Worsnop, D. R., and Jimenez, J. L.: Interpretation of organic components from Positive Matrix Factorization of aerosol mass spectrometric data, Atmos. Chem. Phys., 9, 2891-2918, doi:10.5194/acp-9-2891-2009, 2009. 
Wiedinmyer, C., Quayle, B., Geron, C., Belote, A., McKenzie, D., Zhang, X., O'Neill, S., and Wynne, K. K. : Estimating emissions from fires in North America for air quality modeling, Atmos. Environ., 40, 3419-3432, 2006.

Wiedinmyer, C., Akagi, S. K., Yokelson, R. J., Emmons, L. K., AlSaadi, J. A., Orlando, J. J., and Soja, A. J.: The Fire INventory from NCAR (FINN): a high resolution global model to estimate the emissions from open burning, Geosci. Model Dev., 4, 625641, doi:10.5194/gmd-4-625-2011, 2011.

Yokelson, R. J., Urbanski, S. P., Atlas, E. L., Toohey, D. W., Alvarado, E. C., Crounse, J. D., Wennberg, P. O., Fisher, M. E., Wold, C. E., Campos, T. L., Adachi, K., Buseck, P. R., and Hao, W. M.: Emissions from forest fires near Mexico City, Atmos. Chem. Phys., 7, 5569-5584, doi:10.5194/acp-7-5569-2007, 2007.

Yokelson, R. J., Crounse, J. D., DeCarlo, P. F., Karl, T., Urbanski, S., Atlas, E., Campos, T., Shinozuka, Y., Kapustin, V., Clarke, A. D., Weinheimer, A., Knapp, D. J., Montzka, D. D., Holloway, J., Weibring, P., Flocke, F., Zheng, W., Toohey, D., Wennberg, P. O., Wiedinmyer, C., Mauldin, L., Fried, A., Richter, D., Walega, J., Jimenez, J. L., Adachi, K., Buseck, P. R., Hall, S. R., and Shetter, R.: Emissions from biomass burning in the Yucatan, Atmos. Chem. Phys., 9, 5785-5812, doi:10.5194/acp-9-5785-2009, 2009.
Yokelson, R. J., Burling, I. R., Urbanski, S. P., Atlas, E. L., Adachi, K., Buseck, P. R., Wiedinmyer, C., Akagi, S. K., Toohey, D. W., and Wold, C. E.: Trace gas and particle emissions from open biomass burning in Mexico, Atmos. Chem. Phys., 11, 67876808, doi:10.5194/acp-11-6787-2011, 2011.

Yokelson, R. J., Burling, I. R., Gilman, J. B., Warneke, C., Stockwell, C. E., de Gouw, J., Akagi, S. K., Urbanski, S. P., Veres, P., Roberts, J. M., Kuster, W. C., Reardon, J., Griffith, D. W. T., Johnson, T. J., Hosseini, S., Miller, J. W., Cocker III, D. R., Jung, H., and Weise, D. R.: Coupling field and laboratory measurements to estimate the emission factors of identified and unidentified trace gases for prescribed fires, Atmos. Chem. Phys., 13, 89-116, doi:10.5194/acp-13-89-2013, 2013. 